\title{
Colorectal Carcinoma in the Young
}

\author{
Shahana Gupta ${ }^{*}$ and Anadi Nath Acharya ${ }^{2}$ \\ ${ }^{1}$ Department of Surgery, Medical College $\mathcal{E}$ Hospitals Kolkata, \\ ${ }^{2}$ Department of Surgery, \\ Institute of Post Graduate Medical Education and Research, Kolkata, \\ India
}

\section{Introduction}

Colorectal cancer (CRC) is the most common malignancy of the gastrointestinal tract. In the United States, it is the third most commonly diagnosed cancer, next only to breast and lung. It is the second most common cause of cancer-related death both in the USA and in the UK. (www. cancer. org, $\mathrm{O}^{\prime}$ Connell et. al. 2004a, Leff et. al. 2007). Its incidence has risen rapidly in Asia to pose a problem (Yuen et. al. 1997, Huang et. al. 1999, Mohandas et. al. 1999, Yiu et. al. 2004, Goh et. al. 2005,Gupta et. al. 2010). Sung et. al. (2005) in a review on CRC in Asia stated that many Asian countries, e. g., China, Japan, South Korea, Singapore have experienced an increase of two to four times in CRC incidence during the past few decades. In Hong-Kong CRC is the second most common cancer and the third most common cause of cancer death (Yuen et. al. 1997). Tamura et. al. (1996) in a Japanese study reported that age adjusted incidence for CRC per 100,000 population were 12. 6 and 8.7 for males and females respectively in 1974, 20 and 13. 6 in 1980, 42.5 and 25. 6 in 1991. Bae et. al. (2002) estimated on the basis of Korean data, that the expected number of cancer deaths in Korea showed an increasing trend for CRC, although the same did not hold for all cancers. In Iran, age adjusted CRC incidence per 100,000 population per year increased from 1. 61 in 1970-80 to 4. 2 in 19902000 in men and 2. 35 to 2. 72 for women (Hosseini et. al. 2004). The rising trend is more striking in affluent than in poorer societies and differs substantially amongst ethnic groups. Changes in dietary habits and lifestyle are recognized causes. Genetic characteristics of a population mediate the effect of life style change into disease propensity (Lin et. al. 2010).

Although the common perception is that it is a disease of an older person, there have been many reports from different parts of the world on CRC in the young adults (Bulow 1980, Denmark; Ohman 1982, Sweden;Jarvinen and Turunen 1984, Finland; Ibrahim and Karim 1986, Lebanon; Adloff et. al. 1986, France; Isbister and Fraser 1990, New Zealand; Yuen et. al. 1997, Hong-Kong; Fante et. al. 1997, Italy; Ashenafi 2000, Ethiopia; deSilva et. al. 2000, Srilanka; Paraf and Jothy 2000, Canada; Turkiewicz et. al. , 2001, Australia; Singh et. al. 2002a, Nepal; Kam et. al. 2004, Malayasia; Frizis et. al. 2004, Greece; Guraya and Eltinay2006, Saudi Arabia; Fazeli et. al. 2007, Iran; Karsten et. al. 2008, USA; Gupta et. al. 2010, India). O'Connell et. al. (2004a) have reviewed the literature. The proportion of patients in the young group in a population of CRC patients was significantly larger in reports from Asia and Africa, as compared to the Western reports.

${ }^{*}$ Corresponding Author 
The definition of 'Young adults' varies, to a small extent, in the literature. Majority of articles defined 'young' as <40 years, although upper limits of 50 years, 35 years and 30 years have also been used. O'Connell et. al. (2004) estimated the average value of incidence of CRC in the young adults ( $<40$ years) in the population of all CRC patients as $7 \%$ and adjusted it to $6 \%$, when outliers were removed. It has been suggested (Hamilton 2005) that the adjustment was 'too small' and a more realistic estimate was an average of 2. $2 \%$. Leff et. al. (2007) gave an estimate of $2-3 \%$. About $0.1 \%$ of all CRC patients were diagnosed $<20$ years of age, $\sim 1 \%$ between $20-34$ years, $\sim 4 \%$ between $35-44$ years and a further $\sim 12 \%$ between $45-54$ years. These average figures reflect the extent of the problem in the West. The figures from Asian and African countries are considerably higher, a quarter or a half of a study group of CRC patients may belong to the under-40 group (Ashenafi 2000, Ethiopia; deSilva et. al. 2000, SriLanka; Singh et. al. 2002a, Nepal; Guraya and Eltinay 2006, Saudi Arabia; Gupta et. al. 2010, India). Numerical values given later will establish that the problem of CRC in the young adult in the developing world is alarming.

We now cite reports, from the West (USA, France, Scotland) and from Asia (Iran, Hong Kong), in which the incidence of the disease amongst the young adults has been studied in the same population over a period of time. O'Connell et. al. (2003) noted that in the USA, colon cancer incidence in older patients (60 + years) remained stable in the period 1973-1999 while rectal cancer incidence decreased by $11 \%$. In the group of younger patients (20-40 years) colon cancer incidence increased by $17 \%$, while rectal cancer incidence rose by $75 \%$ in the period $1973-1999$. The improvement in the older age group is a reflection of more efficient cancer screening in the USA, a result of improved awareness of the disease. It is possible that relative ignorance about the problem of CRC in the young adult is responsible for the fact that the problem has worsened over the years. Other issues namely difference in molecular genetics, may also be present. In Iran, Hosseini et. al. (2004) defined the younger group as <60 years, compared figures in two 10 year periods 1970-1980 and 1990-2000 and found an increased proportion of $<60$ years CRC patients (in a population of all CRC patients) in the latter decade, $37.5 \%$ as against $70 \%$. An increase in proportion of the young CRC patients was noted over a prolonged time span. Mitry et. al. (2001) from France reported that below-45 age standardized incidence rates doubled in the period 1976-1982 and then again in the period 1983-1989, in both genders and stabilized thereafter. In Hong-Kong, the overall incidence in > 50 years group increased at a rate of $4 \%$ a year during 1978-87, whereas in Scotland a higher overall incidence remained stable during this period (Yuen et. al. 1997).

$\mathrm{O}^{\prime}$ Connell et. al. (2004 ) in a study of American patients found that young (20-40 years) colon cancer patients tend to have later-stage and higher-grade tumours. However they have equivalent or better 5 year cancer-specific survival compared to $60+$ older group, an apparently paradoxical result. Although most reports agree on a more severe advanced disease at presentation in the young (Adloff et. al. 1986, Cusack et. al. 1996, Nath et. al. , 2009) and many also agree with the opinion that prognosis is not poorer in the young (Jarvinen and Turunen 1984, Turkiewicz et. al. 2001, Karsten et. al. 2008) some reports (Moore et. al. 1984, Adkins et. al. 1987, Okuno et. al. 1987, Singh et. al. 2002a) do not share the view that prognosis is 'equivalent or better'. Inspite of this difference in assessment, a favourable prognosis in many studies should inspire more aggressive detection and treatment for the young.

The genetic basis of CRC has been investigated in recent years. A satisfactory understanding of the disease, tumour characteristics, relationship of disease susceptibility with age and issues related to survival rely on an understanding of the link between molecular genetics and disease. A complete resolution of this relation is a tall order, but a modest beginning is 
being made. Intelligent choice of treatment protocol, surgical as well as chemotherapeutic is also influenced by research on molecular genetics of CRC (Liang and Church 2010). Hereditary CRC usually occurs at a relatively young age, between 25 and 55 years in individuals with family history of CRC. Individuals who inherit the predisposing cancer gene have a greater chance of developing the disease (Murday and Slock 1989, Lynch et. al. 1991, Lynch and de la Chapelle 2003, Ewart Toland, 2012). The importance of family history in determining susceptibility to CRC in the young has been stressed in the literature (St. John et. al. 1993, Fuchs et. al. 1994, Turkiewicz et. al. 2001). There exist literature reports that identify genetic factors in younger CRC patients which differ from those in older patients and may be responsible for greater cancer susceptibility of the younger patients (Farrington et. al. 1998, Chan et. al. 1999, Morris et. al. 2007, Berg et. al. 2010, Lin et. al. 2010).

In this essay, we focus on the issue of CRC in young age, with particular reference to developing countries. The relative incidence figures of CRC in the young patients as compared to older patients in different parts of the world are given. These figures, in greater detail are given in the Indian context (section 2). Disease stage at presentation and tumour characteristics of younger patients, often in comparison with the older ones in different countries are then summarized (section 3). A brief reference to de novo cancer in Asians (section 4) is followed by a discussion of some recent genetic studies in the young (section 5). Section 6 contains a discussion on prediosposing factors and section 7 has focus on prognosis in the young. The paper concludes (section 8 ) with a brief reference to the effect of recent molecular genetic research on treatment protocol.

\section{Incidence amongst young adults}

The relative incidence of CRC in the younger group varies significantly from one country to another. As cited above, it is typically $2-3 \%$ in the West. Other European figures are: Fante et. al. (Italy): 1\%; Endreseth et. al. (Norway):6\%; Ohman (Sweden): 4\%; Adloff et. al. (France): $3 \%$; Yilmazlar et. al. (Turkey): $20 \%$. The corresponding figures are much higher from several Asian and African countries: Nath et. al. (India): 35. 6\%, <40 yrs; Gupta et. al. (India): $39 \%,<40$ years; Singh et. al. (South Asia): $23 \%,<40$ years (with a maximum incidence in $40-60$ years, a decade earlier than Western figures): study period 1975-1981; Soliman et. al. (Egypt): 35. $6 \%,<40$ yrs; Ashenafi (Ethiopia): mean age 47 years $(61.4 \%<50$ years, $36 \%<40$ yrs, $16 \%$ $<30 \mathrm{yrs}$ ) in two 5 year periods with a 10 year gap; Guraya and Eltinay (Saudi Arabia): study period 1999-2004,63\% < 40 yrs, mean age 44years, peak incidence 30-39 years; Hosseini et. al. (Iran): 70\% (<60 years):study period 1990-2000; Chew et. al. (Singapore):25\% <40 years; Singh et. al. (Nepal): 28. 6\% < 40 years; de Silva et. al. (Sri Lanka): 19. 7\% <40 years. Some of these references are detailed in Table 1. In Egypt, more than half of all CRC patients are below-50, patients under- 30 constitute $22 \%$ of the population of all CRC patients (Soliman et. al. 1997). Qing et.al. (2003) in a comparative study of American and Chinese patients (19902000) reported that the mean age at diagnosis of 690 American patients was 69 years (20-91 years) and that of 870 Chinese patients was 48 . 3 years (13-84 years); peak incidence was 7079 years in Whites and 50-59 years in Orientals. The conclusion is that the Orientals are affected by the disease at a younger age. The same theme emerges from recent data from several Indian hospitals which includes our own recent work (Gupta et. al. 2010). In a period spanning 8 years (2000-2008), we found the ratio of under- 40 to above- 40 years age group to be 0.64 . The study group comprised of 305 patients in SSKM Hospital, Kolkata, India, a premier referral Hospital. The values reported by three premier Oncology centers located in two cities in India and in another report by Pal (2006), based on work done 


\begin{tabular}{|c|c|c|c|c|}
\hline $\begin{array}{l}\text { Sr. } \\
\text { No. }\end{array}$ & $\begin{array}{c}\text { Reference, } \\
\text { Period of study }\end{array}$ & Age profile & Disease stage & Tumour characteristics \\
\hline 1 & $\begin{array}{c}\text { Lee } \\
\text { 1968-91 }\end{array}$ & $\begin{array}{c}62 \text { patients, } \\
<40 \mathrm{yrs}\end{array}$ & $\begin{array}{c}\text { Dukes' A: } 8 \%, \\
\text { B:20\%, C:23\%, } \\
\text { D: } 48 \% .\end{array}$ & $\begin{array}{l}\text { Half of stage D patients } \\
\text { and } 20 \% \text { of lower stage } \\
\text { patients ( } \mathrm{p}=0.037) \\
\text { had high grade lesions. }\end{array}$ \\
\hline 2 & $\begin{array}{l}\text { Minardi, } \\
\text { 1976-97 }\end{array}$ & $\begin{array}{c}37 \text { patients, } \\
\text { <40yrs }\end{array}$ & $\begin{array}{c}\text { Dukes' C:37\%, } \\
\text { D: } 22 \% .\end{array}$ & $\begin{array}{c}\text { Mucinous tumour: } \\
42 \% \text {; moderate and } \\
\text { poor differentiation : } \\
84 \%\end{array}$ \\
\hline 3 & Cusack & $\begin{array}{c}186 \text { patients, } \\
<40 y r s\end{array}$ & $\begin{array}{c}\text { Dukes' C \& D: } \\
65.6 \% .\end{array}$ & $\begin{array}{c}\text { Poorly differentiated } \\
\text { tumour in } 41 \% \text {, signet- } \\
\text { ring cell tumours in } 11 . \\
1 \%, \text { infiltrating tumour } \\
\text { leading edges in } 69 \% \\
\text { of young patients. } \\
\text { Aggressive tumour } \\
\text { biology with higher } \\
\text { frequency in <40yr } \\
\text { patients } \\
\text { (p<0. 001), potentially } \\
\text { metastatic. }\end{array}$ \\
\hline 4 & $\begin{array}{l}\text { Bedikian, } \\
\text { 1944-1977 }\end{array}$ & $\begin{array}{c}2609 \\
\text { patients, }<50 \mathrm{yrs} \\
\text { age; } 183 \\
\text { aged }<40 \mathrm{yrs} \text {. } \\
\text { Comparison } \\
\text { between }<30 \mathrm{yr} \\
\text { and } 30-39 \mathrm{yr} \\
\text { age group and } \\
\text { with yet } \\
\text { older age } \\
\text { group }\end{array}$ & $\begin{array}{l}96 \% \text { of }<40 \text { years } \\
\text { group had } \\
\text { carcinoma } \\
\text { extending beyond } \\
\text { colonic wall. }\end{array}$ & $\begin{array}{l}\text { Moderate and poorly } \\
\text { differentiated } \\
\text { neoplasms }(80 \%) \text { and } \\
\text { mucinous variety } \\
(33 \%) \text { in young. }\end{array}$ \\
\hline 5 & $\begin{array}{l}\text { Beckman } \\
1943-1977\end{array}$ & $\begin{array}{c}69 \text { patients: } 20- \\
\text { 39yrs }\end{array}$ & $\begin{array}{c}\text { 67\% Dukes' } \\
\text { C and D }\end{array}$ & $\begin{array}{c}\text { Mucinous variety } \\
(28 \%) \text {. }\end{array}$ \\
\hline 6 & Varma & $\begin{array}{l}\text { A review: } \\
\text { all age groups }\end{array}$ & $\begin{array}{l}\text { Advanced stage } \\
\text { more frequent in } \\
\text { the young. }\end{array}$ & $\begin{array}{l}\text { Greater frequency of } \\
\text { mucinous tumour in } \\
\text { the young. }\end{array}$ \\
\hline 7 & $\begin{array}{c}\text { Cozart, } \\
\text { Unusual Case } \\
\text { Registry } \\
1992-93\end{array}$ & $\begin{array}{c}55 \text { patients, } \\
<30 y r s\end{array}$ & $\begin{array}{c}62 \% \text { Dukes' } \\
\text { C and D }\end{array}$ & $\begin{array}{l}\text { Poorly differentiated } \\
\text { /mucinous variety: } \\
33 \%\end{array}$ \\
\hline 8 & Howard & $\begin{array}{l}801 \text { patients } \\
\text { including } \\
<40 \text { yrs group }\end{array}$ & $\begin{array}{c}\text { Advanced signs } \\
\text { and stages more } \\
\text { frequent in the } \\
\text { young. }\end{array}$ & $\begin{array}{c}\text { Greater frequency of } \\
\text { mucinous variety in the } \\
\text { young }\end{array}$ \\
\hline
\end{tabular}




\begin{tabular}{|c|c|c|c|c|}
\hline 9 & $\begin{array}{l}\text { Adkins, } \\
\text { 1973-1984 }\end{array}$ & $\begin{array}{c}705 \text { patients; } \\
45 \text { patients, } \\
\text { <35yrs }\end{array}$ & $\begin{array}{l}\text { In the younger } \\
\text { group: } \\
\text { Dukes' A:2,B:8, } \\
\text { C: } 28, D: 7 \\
\text { patients. }\end{array}$ & $\begin{array}{c}\text { 19: poorly } \\
\text { differentiated,19: } \\
\text { well or moderately } \\
\text { differentiated } \\
\text { tumour }\end{array}$ \\
\hline 10 & $\begin{array}{c}\text { Moore, } \\
1967-1981\end{array}$ & $\begin{array}{l}\text { 3. } 2 \% \text { of } 1909 \\
\text { patients < } 40 \mathrm{yrs}\end{array}$ & $\begin{array}{l}\text { Higher incidence } \\
\text { of advanced } \\
\text { disease, especially } \\
\text { in second or third } \\
\text { decades. }\end{array}$ & $\begin{array}{l}\text { Greater incidence of } \\
\text { mucinous variety } \\
\text { (32. 3\% in young } \\
\text { vs. } 8.6 \% \text { in the } \\
\text { whole study } \\
\text { group). Poorly } \\
\text { differentiated } \\
\text { tumour: } 98 \% \text {; } \\
\text { distant metastases in } \\
\text { one-third patients. } \\
\text { Vascular (24\%) } \\
\text { and perineural } \\
\text { (11\%) invasion in the } \\
\text { young. } \\
\end{array}$ \\
\hline 11 & $\begin{array}{l}\text { Karsten. , } \\
1998-2005\end{array}$ & $\begin{array}{l}\text { Younger } \\
\text { group: } \\
41 \text { patients } \\
\text { <40yrs } \\
\text { Older group: } \\
\text { >60 yrs }\end{array}$ & $\begin{array}{l}\text { Advanced stage: } \\
\text { T-3/4 lesion in } 87 . \\
8 \% \text { of young } 63 \% \\
\text { in older group } \\
\quad(p=0.002) .\end{array}$ & $\begin{array}{l}\text { Poorly differentiated, } \\
(\mathrm{p}=0.003), \\
\text { mucin secreting/ } \\
\text { signet ring } \\
(\mathrm{p}=0.005), \\
\text { more common in the } \\
\text { young }\end{array}$ \\
\hline 12 & $\begin{array}{c}\text { Fairley, } \\
\text { 1998-2001 } \\
\text { Cancer Registry } \\
\text { (NPCR,SEER)* }^{*}\end{array}$ & $\begin{array}{l}\text { All age groups } \\
\text { Young:20-49yrs }\end{array}$ & $\begin{array}{l}\text { Less localized, } \\
\text { more aggressive } \\
\text { disease in terms of } \\
\text { stage in the young } \\
(20-49 \mathrm{yrs})\end{array}$ & $\begin{array}{c}\text { Incidence of poorly } \\
\text { differentiated } \\
\text { tumour in young } \\
(<50 \mathrm{yrs})(\mathrm{i}) \text { twice as } \\
\text { high as well } \\
\text { differentiated } \\
\text { ones in the } \\
\text { young (ii) } 60 \% \\
\text { higher than that } \\
\text { for well } \\
\text { differentiated } \\
\text { cancers in } \\
\text { the old }\end{array}$ \\
\hline 13 & $\begin{array}{l}\text { Lichtman } \\
1987-1991\end{array}$ & $57.2 \%<70 y r s$ & $\begin{array}{c}\text { Dukes' C and D } \\
\text { more frequent at a } \\
\text { lower age } \\
\text { (p=0.03). } \\
\text { Mean Age A/B-1 } \\
67.7 \text { yrs, B-2 70. } \\
\text { 1yrs, C/D 63. 9yrs }\end{array}$ & $\begin{array}{l}\text { Grade not } \\
\text { related to age }\end{array}$ \\
\hline
\end{tabular}




\begin{tabular}{|c|c|c|c|c|}
\hline 14 & $\begin{array}{c}\text { Dozois, } \\
1976-2002\end{array}$ & $\begin{array}{c}1025 \\
\text { patients, }<50 \mathrm{yrs} ; \\
\text { Mean age } 42 . \\
4 \pm 6.4 \text { years } \\
51 \% \text { colon, } 49 \% \\
\text { rectal (largest } \\
\text { cohort of } \\
\text { young-onset } \\
\text { patients } \\
\text { without genetic } \\
\text { predisposition) }\end{array}$ & $\begin{array}{l}70 \% \text { colon, } \\
60 \% \text { rectal: } \\
\text { stage C\&D }\end{array}$ & $\begin{array}{l}\text { Colon Cancer: } \\
\text { Mucinous }(11 \%) \& \\
\text { Signet cell }(2 \%) \\
\text { Grade } 2+3 \text { for both } \\
\text { rectum \& colon cancer: } \\
\sim 87 \%\end{array}$ \\
\hline 15 & $\begin{array}{l}\text { Behbehani } \\
11 \text { yrs period } \\
\text { pre-1980 }\end{array}$ & $\begin{array}{l}<40 \text { years } \\
\text { group: } \\
56 \text { patients }\end{array}$ & $\begin{array}{l}\text { Advanced stage } \\
\text { C\&D: } \sim 90 \% \text { in } \\
\text { young } \\
\sim 50 \% \text { in general } \\
\text { population }\end{array}$ & $\begin{array}{l}\text { Poor differentiation: } \\
21 \% \text { in young, } 8 \% \text { in } \\
\text { general population }\end{array}$ \\
\hline
\end{tabular}

*NPCR: National Program of Cancer Registries; SEER: Surveillance, Epidemiology and End Results

Table 1. Summary of references in the literature on stage and tumour characteristics in the USA

in the same referral hospital where Gupta et. al. (2010) worked are 0. 58, 0. 63, 0. 45, 0. 62. Average of these five ratios is 0.52 , which is equivalent to $\sim 34 \%$ of $<40$ years CRC patients amongst all CRC patients. This figure is of the same order as the values from several Asian and African countries cited above. They are also substantially larger than values recorded in National Cancer Registry (PBCR) in four Indian metropolises. The PBCR ratio is 0.20 and has remained stable over 16 years (1988-2004).

The difference between PBCR values and those reported by five premier hospitals in India, irrespective of their location and specialty, cited by Gupta et. al. (2010) has a clear message. The concern and facilities for cancer detection in the premier hospitals is greater than those in district hospitals. The data of the district hospitals are reflected in the PBCR values. This is the reason for the larger proportion of under-40 patients reported by the premier hospitals. The reason for delay in diagnosis of a young patient in either the premier hospitals or the district hospitals, particularly in the developing world, is that unless there is a family history these patients are not screened. So cancers are usually symptomatic at presentation. Even when symptoms occur, they may initially be misdiagnosed. Rectal bleeding for example is often put down to an anorectal cause. $\mathrm{O}^{\prime}$ Connell et. al. (2004a) report an average delay in diagnosis of 6.2 months, the reasons for which include a delay in presentation on the part of the patients, limited access to care and misdiagnosis on the part of the physician. This delay is larger in the developing world. Minimizing delay in diagnosis means not taking such symptoms lightly. Rectal bleeding usually has an anorectal cause, but when no such cause is obvious and the bleeding persists, colonoscopy is mandatory, regardless of patient's age. The same concern must apply to other less obvious symptoms.

In a review on CRC in Asia, Sung et. al. (2005) placed India at the bottom of the list amongst Asian countries, in order of decreasing CRC incidence. The data we provide does not contradict this assessment, but if relative incidence in the young is an indication, India has joined the rest of Asia. 


\section{Disease stage and tumour characteristics in the young adults}

The most powerful predictor of outcome for young adults, as it is for older patients is disease stage. Two staging systems are in use and are cited in Table 1-3. One is the tumournode-metastases (TNM) staging system of the American Joint Committee on Cancer (AJCC). Microscopic extent of tumour invasion ( $\mathrm{T}$ stage) and nodal involvement ( $\mathrm{N}$ stage) from histological assessment are combined with assessment for metastatic disease ( $\mathrm{M}$ stage) to specify a tumour stage. Brief description of TNM stages are: Tumour stages (T): Tumour in T1, invades submucosa, T2: invades muscularis propria, T3 and T4 are more extensive, T3 indicates invasion through muscularis propria into subserosa or into nonperitonealised pericolic or perirectal tissues while T-4 invades adjacent organs. Regional Lymph node stages: N1: 1-3 positive nodes, N2:4 or more positive nodes. Distant metastases stages (M): M1: Distant metastases present. The other classification system known as Dukes' system is: A: limited to bowel wall, B: penetration of bowel wall, C: lymph node involvement, D: distant metastatic disease present (Fry et. al. 2008).

Mucinous adenocarcinoma is one of the histological subtypes of colorectal cancers. It accounts for $5-15 \%$ of all primary CRC and is defined as a tumour with $>50 \%$ of its body showing a mucinous pattern on histological examination and with a large amount of extra cellular mucin produced by secreting acini. This is distinct from signet ring adenocarcinoma, a rare variant in which mucin remains inside the cell, which is well known for its aggressiveness. It has been suggested that mucinous adenocarcinoma behaves differently from more common histological subtypes of CRC. However, its clinical implications remain unclear. According to published series, mucinous adenocarcinoma affects younger patients, is more frequent in proximal part of the colon and tends to present at a more advanced stage (Negri et. al. 2005).

In Table 1, 2 and 3 we tabulate data on disease stage and tumour characteristics, in particular its mucinous nature, of CRC patients in the USA (Table 1), in Europe, inclusive of Turkey and the UK and Australia (Table 2) and in Asia and Africa (Table 3).

Several reports cited in Table 1 (Sr No 1,2,3,5,7,9,14) were entirely on features of CRC in the younger patients. In several other reports (Sr No. 4,6,8,10-13,15), both the younger and the older patient groups were studied and comparative features were assessed. The size of the younger group was mostly $\sim 50$, was $\sim 200$ in two reports ( $\mathrm{Sr} N o 3$ and 4) and was 1025 in the work of Dozois et. al. (2005) (Sr no 14), the largest cohort of young CRC patients. In reports that included older and younger patients, older patients were much larger in number (Sr No 4,8-10). In all studies that were on younger patients alone, a high incidence of advanced stage $(\mathrm{C}+\mathrm{D}$ : $>70 \%)$ was reported. In studies that included both groups, the frequency of advanced disease in the young was as high or higher (Sr No. $4,11,15)$. In all of them, advanced disease stages were found to be more frequent in the young than in the old. In studies on younger patients alone, a significant proportion of patients had aggressive lesions, namely mucinous, poorly differentiated tumours with infiltrating leading edge. The frequency of aggressive tumour biology varied from one study to another but remained significant in all of them. In the comparative studies (Sr No. 6,8,10-12,15), the younger patients showed a higher frequency of aggressive tumour biology. Only one report (Sr No. 13) concluded that grade was not related to age. 


\begin{tabular}{|c|c|c|c|c|c|}
\hline Country & $\begin{array}{l}\text { Sr } \\
\text { No. }\end{array}$ & $\begin{array}{c}\text { Reference, } \\
\text { Period of } \\
\text { study } \\
\end{array}$ & Age profile & Disease stage & $\begin{array}{c}\text { Tumour } \\
\text { characteristics }\end{array}$ \\
\hline France & 1 & $\begin{array}{c}\text { Adloff } \\
1973-1980\end{array}$ & $\begin{array}{l}1037 \\
\text { patients; 3\% } \\
<40 \mathrm{yrs}\end{array}$ & $\begin{array}{c}\text { No significant } \\
\text { difference in stage } \\
\text { between }<40 \text { and }>40 \\
\text { Yrs group. }\end{array}$ & $\begin{array}{l}\text { Greater frequency } \\
\text { of mucinous and } \\
\text { poorly } \\
\text { differentiated } \\
\text { carcinoma } \\
\text { in the } \\
\text { young } \\
\end{array}$ \\
\hline Finland & 2 & $\begin{array}{l}\text { Jarvinen } \\
1970-1979\end{array}$ & $\begin{array}{c}249 \text { patients, } \\
<40 \mathrm{yrs}\end{array}$ & 53\% Dukes' C and D. & $\begin{array}{l}\text { Premalignant } \\
\text { condition } \\
\text { more common in } \\
\text { young }\end{array}$ \\
\hline Greece & 3 & $\begin{array}{c}\text { Frizis } \\
1994-2003\end{array}$ & $\begin{array}{c}\text { Two } \\
\text { groups: } 11 \\
\text { young } \\
<40 y r s ; 45 \\
\text { old > } 80 \text { yrs. }\end{array}$ & 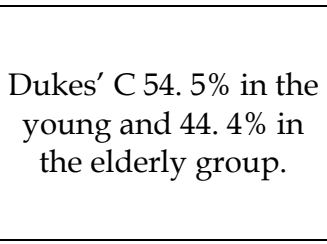 & $\begin{array}{c}\text { Undifferentiated } \\
\text { tumour: } \\
36.3 \% \\
\text { of the young and } \\
8.8 \% \\
\text { of elderly. }\end{array}$ \\
\hline Sweden & 4 & $\begin{array}{c}\text { Ohman } \\
\text { 1950-1979 }\end{array}$ & $\begin{array}{c}48 / 1061 \\
\text { patients are } \\
<40 \text { years } \\
(21-39 \\
\text { years) }\end{array}$ & $\begin{array}{c}\text { Dukes' A same } \\
\text { proportion in young } \\
\text { and old, } \\
\text { Dukes' B fewer, } \\
\text { Dukes' C more } \\
\text { in young } \\
\end{array}$ & \\
\hline \multirow[t]{2}{*}{ Norway } & 5 & $\begin{array}{l}\text { Endreseth } \\
\text { 1993-1999 }\end{array}$ & $\begin{array}{c}2283 \\
\text { patients } \\
\text { with rectal } \\
\text { cancer }<70 \\
\text { years, } \\
<45 \text { yrs: } 132, \\
45-49 \text { yrs: } \\
153 \\
50-69 \\
\text { yrs:1998 }\end{array}$ & $\begin{array}{c}\text { Dukes' C\&D : } \\
\text { under 45: } \\
\text { 73/132( 55\%) } \\
\text { 45-69yrs: } \\
\text { 998/2152( 46\%) }\end{array}$ & $\begin{array}{c}\text { Higher frequency } \\
\text { of poorly } \\
\text { differentiated } \\
\text { tumours } \\
\text { (27 vs. } 15 \%) \& \mathrm{~N}-2 \\
\text { stage ( } 37 \text { vs. } 15 \%) \\
\text { with distant } \\
\text { metastases ( } 38 \text { vs. } \\
20 \%) ; \\
56 \% \text { of under- } 40 \\
\text { years: developed } \\
\text { metastases } \\
\text { (20-26\% of older } \\
\text { group) } \\
\text { after tumour } \\
\text { resection }\end{array}$ \\
\hline & 6 & $\begin{array}{l}\text { Berg } \\
2010\end{array}$ & $\begin{array}{c}181 \text { patients, } \\
45 \text { of them < } \\
50 \text { yrs }\end{array}$ & $\begin{array}{c}\text { Dukes' } C \& D \\
54 \% \text { in }<50 \text { yrs group } \\
46 \% \text { in } 51-70 \text { yrs } \\
36 \% \text { in }>70 \text { yrs }\end{array}$ & \\
\hline
\end{tabular}




\begin{tabular}{|c|c|c|c|c|c|}
\hline Country & $\begin{array}{l}\text { Sr } \\
\text { No. }\end{array}$ & $\begin{array}{l}\text { Reference, } \\
\text { Period of } \\
\text { study }\end{array}$ & Age profile & Disease stage & $\begin{array}{c}\text { Tumour } \\
\text { characteristics }\end{array}$ \\
\hline UK & 7 & $\begin{array}{c}\text { Leff } \\
1982-1992\end{array}$ & $\begin{array}{c}49 \text { patients } \\
\text { all } \\
\text { < } 40 \text { yrs: } \\
67 \% \text { in } 31-40 \\
\text { yrs, } 2 \text { in } \\
\text { their teens }\end{array}$ & $\begin{array}{l}\text { Among all patients: } \\
60 \% \text { Dukes' C\&D. } \\
\text { Among patients at } \\
\text { risk (family history } \\
\text { /predisposing factor): } \\
56 \% \text { Dukes' C }\end{array}$ & $\begin{array}{c}\text { Among all patients: } \\
59 \% \text { moderately \& } \\
22 \% \text { poorly } \\
\text { differentiated } . \\
\text { Among patients at } \\
\text { risk: } 53 \% \\
\text { moderately \& } 20 \% \\
\text { poorly } \\
\text { differentiated } \\
\end{array}$ \\
\hline Italy & 8 & $\begin{array}{c}\text { Fante } \\
1984-1992\end{array}$ & $\begin{array}{c}\text { Three } \\
\text { groups }<40, \\
41-50, \\
51-55 \text { years: } \\
\sim 1 \%, 6 \%, \\
6 \% \text { of } 1298 \\
\text { patients } \\
\end{array}$ & Stage did not differ & $\begin{array}{c}\text { Histological } \\
\text { features did not } \\
\text { differ }\end{array}$ \\
\hline Turkey & 9 & $\begin{array}{l}\text { Yilmazlar } \\
1986-1993\end{array}$ & $\begin{array}{c}237 \text { patients; } \\
46 \text { below } \\
40 y r s\end{array}$ & $\begin{array}{l}76 \% \text { of the young: } \\
\text { Dukes C\&D }\end{array}$ & $\begin{array}{l}48 \% \text { tumours are } \\
\text { poorly } \\
\text { differentiated or } \\
\text { mucinous in } \\
\text { young. }\end{array}$ \\
\hline Australia & 10 & $\begin{array}{c}\text { Turkiewitz } \\
\text { 1971-1999 }\end{array}$ & $\begin{array}{c}61 / 2384 \\
\text { below } 40 \\
\text { years }\end{array}$ & $\begin{array}{c}\text { Distribution of stage } \\
\text { not significantly } \\
\text { different in } \\
\text { younger and older } \\
\text { group }\end{array}$ & $\begin{array}{l}35 \% \text { tumours in the } \\
\text { young are poorly } \\
\text { differentiated }\end{array}$ \\
\hline
\end{tabular}

Table 2. Summary of references in the literature on stage and tumour characteristics from Europe (inclusive of UK \& Turkey) and Australia

Two of the reports from Europe listed in Table 2 (Sr.No.2,7) are entirely on young patients. One of these ( $\mathrm{Sr}$ No. 2) has the largest study group of young onset patients ( 250), while the other reports have $\sim 100-150$ (Sr Nos. 5,6,8) or less $\sim 50$ (Sr No. $1,4,7,10)$ young patients. The report, Sr No. 3 is on a much smaller population of 11 patients. A significant frequency of more advanced $(C+D)$ tumour in the young $(50-60 \%)$ was reported in several studies (Sr No. 2,3,5-7). This frequency was larger (76\%) in a study from Turkey (Sr No. 9). Comparative assessment showed a higher frequency of advanced stages in the young as compared to that in the older patients (Sr No. 3-6). Significant frequency $(\sim 50 \%)$ of high grade tumours were reported in the young in several publications (Sr Nos. 3,5,7,9,10). Higher frequency of high grade tumours in the young as compared to the older group were cited in several other papers ( $\mathrm{Sr}$ No. 1,3,5,7). Three studies (Sr No. 1,8,10) however, reported no difference in disease stage and one report $(\mathrm{Sr}$ No. 8) found no difference in tumour grade, between the younger and older patient groups. A significant occurrence of premalignant conditions in the young was reported in only one paper (Sr No. 2). 


\begin{tabular}{|c|c|c|c|c|c|}
\hline Country & $\begin{array}{l}\text { Sr } \\
\text { No }\end{array}$ & $\begin{array}{l}\text { Reference, } \\
\text { Period of } \\
\text { Study }\end{array}$ & Age profile & Disease Stage & $\begin{array}{c}\text { Tumour } \\
\text { Characteristics }\end{array}$ \\
\hline $\begin{array}{l}\text { ASIA } \\
\text { Iran }\end{array}$ & 1 & $\begin{array}{c}\text { Fazeli } \\
1995-2001\end{array}$ & $\begin{array}{l}403 \text { patients in } \\
\text { two age } \\
\text { groups, } \\
<40 \mathrm{yrs} \text { and } \\
>40 \mathrm{yrs}\end{array}$ & $\begin{array}{l}\text { Older group: } \\
53.2 \% \text { in stage II; } \\
\text { younger group: } \\
45 \% \text { in stage III. }\end{array}$ & $\begin{array}{c}\text { Poorly } \\
\text { differentiated } \\
\text { tumours } \\
\text { found in larger } \\
\text { proportion in } \\
\text { younger } \\
\text { patients } \\
(22 \% \text { vs. } 5.9 \%) \\
\end{array}$ \\
\hline \multirow[b]{2}{*}{ Singapore } & 2 & $\begin{array}{c}\text { Kam } \\
1989-2001\end{array}$ & $\begin{array}{c}39 \text { patients } \\
<30 \mathrm{yrs}, \\
\text { mean age 25yrs }\end{array}$ & $\begin{array}{c}\text { Advanced disease } \\
\text { stage in } 70 \% \text { patients. }\end{array}$ & $\begin{array}{c}\text { Mucinous } \\
\text { histology: } \\
18 \% ; \\
\text { differentiation: } \\
\text { moderate } \\
61 \%, \\
\text { poor } 36 \%\end{array}$ \\
\hline & 3 & $\begin{array}{c}\text { Chew } \\
\text { 1997-2005 }\end{array}$ & $\begin{array}{l}523 \text { Asian } \\
\text { cohorts } \\
\text { 19-50 years } \\
\text { Of them } \\
\text { <40 yrs:134; } \\
\text { >40yrs:389 }\end{array}$ & $\begin{array}{c}\text { 63\% Advanced stage } \\
\text { (III-IV) } \\
\text { <40yr group: } \\
\text { 89/134;66\% } \\
\text { >40yr group: } \\
245 / 389 ; 63 \%\end{array}$ & $\begin{array}{c}\text { Predominantly } \\
\text { poorly } \\
\text { differentiated: } \\
\text { (30\% in }<40 \\
\text { years } 12 \% \\
\text { in }>40 \text { years) } \\
\text { mucinous, } \\
\text { signet } \\
\text { ring cell } \\
\text { histological } \\
\text { subtypes } \\
\text { (16\% vs. } 9 \%) . \\
\end{array}$ \\
\hline Malaysia & 4 & $\begin{array}{c}\text { Shahruddin } \\
1990-94\end{array}$ & $\begin{array}{c}21 \text { patients } \\
<30 \mathrm{yrs}\end{array}$ & Extensive disease & $\begin{array}{l}\text { Mucinous } \\
\text { histology }\end{array}$ \\
\hline \multirow{2}{*}{ Israel } & 5 & $\begin{array}{l}\text { Shemesh- } \\
\text { Bar, } \\
\text { 1997-2007 }\end{array}$ & $\begin{array}{c}406 \text { patients, } \\
203 \text { in }<50 \\
\text { years }\end{array}$ & $\begin{array}{c}\text { More advanced } \\
\text { stage III-IV at } \\
\text { diagnosis } \\
(56 \text { vs. } 41 \%) \\
\text { higher rate of N-2 } \\
\text { disease } \\
(29 \text { vs. } 16 \%) \\
\end{array}$ & $\begin{array}{l}\text { No difference in } \\
\text { other features }\end{array}$ \\
\hline & 6 & $\begin{array}{l}\text { Neufeld } \\
1999-2005\end{array}$ & $\begin{array}{l}<50 \text { years } 90 ; \\
190>50 \text { years }\end{array}$ & $\begin{array}{c}40 \% \\
\text { Advanced stage } \\
\text { (III-IV) } \\
<40 \mathrm{yrs}: 47 / 90 ; 52 \% \\
>40 \mathrm{yrs}: 61 / 190 ; 32 \%\end{array}$ & $\begin{array}{c}\text { Mucinous } \\
\text { tumour in } \\
11 \% \text { in } \\
\text { early onset } \\
\text { group, } \\
7 \% \text { in late onset } \\
\text { group } \\
\end{array}$ \\
\hline
\end{tabular}




\begin{tabular}{|c|c|c|c|c|c|}
\hline Country & $\begin{array}{l}\text { Sr } \\
\text { No }\end{array}$ & $\begin{array}{c}\text { Reference, } \\
\text { Period of } \\
\text { Study } \\
\end{array}$ & Age profile & Disease Stage & $\begin{array}{c}\text { Tumour } \\
\text { Characteristics }\end{array}$ \\
\hline Taiwan & 7 & $\begin{array}{l}\text { Chiang } \\
7 \text { year period }\end{array}$ & $\begin{array}{l}5436 \text { patients } \\
7 \%<40 \text { years }\end{array}$ & $\begin{array}{c}\text { Dukes' stage } \\
\text { improves with age } \\
\text { (A \& B 31\% } \\
<30 \text { years, } \\
49 \%>80 \text { years) }\end{array}$ & $\begin{array}{c}\text { Poorly } \\
\text { differentiated } \\
\text { tumours tended } \\
\text { to decrease with } \\
\text { age, } \\
16.9 \%<30 \\
\text { years. } \\
6.2 \%>80 \\
\text { years. } \\
\text { Similar trend in } \\
\text { Mucin } \\
\text { producing } \\
\text { characteristics } \\
(36 \% \text { vs7. } 5 \%)\end{array}$ \\
\hline \multirow[t]{2}{*}{ India } & 8 & $\begin{array}{l}\text { Nath } \\
\text { 2003-2007 }\end{array}$ & $\begin{array}{c}287 \text { patients } \\
35.6 \%<40 \mathrm{yrs}\end{array}$ & $\begin{array}{c}\text { Advanced T stage } \\
\text { (T 0-2: } 18.9 \% \\
\text { T -3: } 62.3 \% \text { T-4: } 19 . \\
\text { 7\% vs. } 34.5 \%, 56.0 \%, \\
\text { 9. } 5 \% \text { ) and N-stage (N } \\
\text { 0: } 31.1 \%, \text { N1: } 41 \%, \\
\text { N2: } 27.8 \% \text { vs. } 53.9 \%, \\
26.7 \%, 17.2 \% \text { ) }\end{array}$ & $\begin{array}{c}\text { Poorly } \\
\text { differentiated } \\
\text { and / or } \\
\text { mucinous or } \\
\text { signet cell } \\
\text { carcinoma } \\
(52 \% \text { vs. } 20.5 \%)\end{array}$ \\
\hline & 9 & $\begin{array}{c}\text { Gupta } \\
2000-2008\end{array}$ & $\begin{array}{l}305 \text { patients } \\
40 \%<40 \text { yrs }\end{array}$ & $\begin{array}{l}60 \% \text { presented in } \\
\text { Dukes' stage III \& IV }\end{array}$ & $\begin{array}{c}\text { Mucinous } \\
\text { tumour } \\
80 \% \\
\text { Poor } \\
\text { differentiation } \\
50 \%\end{array}$ \\
\hline Nepal & 10 & $\begin{array}{l}\text { Singh } \\
2002^{a}\end{array}$ & $\begin{array}{c}91 \text { patients } \\
28.6 \%<40 \mathrm{yrs}\end{array}$ & $\begin{array}{c}\text { 92. } 3 \% \text { present in } \\
\text { Dukes' stage III-IV vs. } \\
61.5 \% \text { in older } \\
\text { patients }\end{array}$ & $\begin{array}{l}\text { Significantly } \\
\text { higher } \\
\text { poorly } \\
\text { differentiated } \\
\text { and mucinous } \\
\text { carcinoma } \\
\text { in the } \\
\text { young. } \\
\end{array}$ \\
\hline SriLanka & 11 & $\begin{array}{c}\text { de Silva } \\
15 \text { yr period }\end{array}$ & $\begin{array}{l}305 \text { patients } \\
19.7 \%<40 \mathrm{yrs}\end{array}$ & $\begin{array}{l}\text { No significant } \\
\text { difference in Dukes' } \\
\text { stage with older } \\
\text { group }\end{array}$ & $\begin{array}{c}\text { Significant } \\
\text { presence } \\
\text { of mucinous } \\
(13.3 \%) \text { or } \\
\text { signet } \\
\text { ring type } \\
(5 \%) \text { tumours. }\end{array}$ \\
\hline
\end{tabular}




\begin{tabular}{|c|c|c|c|c|c|}
\hline Country & $\begin{array}{c}\text { Sr } \\
\text { No }\end{array}$ & $\begin{array}{c}\text { Reference, } \\
\text { Period of } \\
\text { Study }\end{array}$ & Age profile & Disease Stage & $\begin{array}{c}\text { Tumour } \\
\text { Characteristics }\end{array}$ \\
\hline AFRICA & 12 & $\begin{array}{c}\text { Soliman* } \\
1982-1996\end{array}$ & $\begin{array}{c}1608 \text { patients; } \\
\text { Egypt }\end{array}$ & $\begin{array}{c}\text { Dukes' stage is } \\
\text { worse in } \\
>40 \text { years group } \\
(72 \% \text { vs. } 57 \%)\end{array}$ & $\begin{array}{c}\text { Tumour grade } \\
\text { comparable in } \\
\text { two groups; } \\
\text { mucin } \\
\text { producing } \\
\text { tumours: } 31 \% \\
\text { in younger } \\
\text { group, } 14 \% \text { in } \\
\text { older group }\end{array}$ \\
\hline
\end{tabular}

*Soliman et. al. (1997)

Table 3. Summary of references in the literature on stage and tumour characteristics from Asia and Africa.

Reports from Asia and Africa are listed in Table 3. Features of only the younger patients were assessed in four reports (Sr. No. 2-4,9). The younger groups were larger in several studies (523:Sr No. 3; 203:Sr No 5; 370: Sr No. 7and 576 : Sr No. 12) from Asia and Africa as compared to ones from the USA (Table 1) and Europe (Table 2). Higher incidence of $\mathrm{CRC}$ in the young in Asia and Africa was found to be consistent with these figures. In two studies (Sr No. 11,12) the disease in the young was assessed as less advanced at presentation and less aggressive. In one report (Sr No. 5), a more advanced disease stage was noted but no difference in tumour grade was found. A more advanced disease and tumour grade was reported in the young as compared to the older patients (which is usually the case in Table $1 \& 2$ ) in 5 of 12 reports (Sr No. 1,6-8,10). In a report by Chew et. al (2009, Sr No. 3) the same conclusion was reached; 'older' patients were however in the age group 40-50years. The frequency of advanced disease and high tumour grade in the young in these reports were similar to that in reports restricted to only the young patients (Sr No. 2,4,9).

Irrespective of the country, the size of the study group, time span and the year of study, the dominant result is the same. Young CRC patients present at a more advanced clinical stage, the tumours are mucinous and poorly differentiated, more so in comparison with the older patient group. The features in India and neighbouring Nepal and Sri Lanka are the same as in the rest of the world. We have noticed some difference in disease pattern in Asia and Africa as compared to the West in our discussions of the data in Tables 1-3. The issue of ethnic differences in determining the difference in disease characteristics is important. This issue, without specific reference to the disease in the young, received attention in several papers, e. g., Isbister (1992; New Zealand and Saudi Arabia), Soliman et. al. (2001; Egypt and the West), Fireman et. al. (2001;Arab and Jewish neighbours in Israel),Qing et. al. (2003;USA and China), Sung et. al. (2005;Asia and the West),Goh et. al. (2005;Asian patients of different races in Malaysia) and Fairley et. al. (2006;Blacks,Asians/Pacific Islanders and Whites).

The advanced stage at presentation of many colorectal cancers in young patients is not just a result of a delay in diagnosis. It may also be that the cancer in younger patients is more virulent by nature. This feature is rooted in subtleties of genetic differences. More aggressive' tumour characteristics, as evidenced by its mucinous nature and poor 
differentiation have also been linked to molecular genetic differences. Recent molecular biology studies have shown characteristic features of mucinous carcinoma, e. g., lower expression of p53, more frequent DNA replication errors expressed as microsatellite instability and specific codon $12 \mathrm{~K}$-ras mutations and, when ploidy has been determined, a higher index if diploidy was found than for non-mucinous carcinoma (Negri 2005).

Tumour subsite: The issue of subsite location is important in screening strategies and in choice of treatment protocols. In the literature (e. g. , Breivik et. al. 1997) preference for subsite location has been associated with molecular genetic roots of CRC. Molecular genetic findings classify CRC into two groups. The first class of tumours show microsatellite instability (MSI), occur more frequently in the right colon, have diploid DNA, behave indolently, of which Hereditary Non polyposis Colorectal Cancer Syndrome (HNPCC) is an example. The larger incidence of proximal colon cancer in patients with HNPCC syndrome highlights the importance of genetics in preference for subsite location in colon cancer. In the other group belong tumours which tend to be left sided, show aneuploid DNA, behave aggressively, of which Familial Adenomatous Polyposis (FAP) is an example. Each group has its own characteristic gene mutations (Lynch and de la Chapelle, 1999).

Breivik et. al. (1997)in a study of 282 patients from 7 hospitals in Norway in the period 19879 concluded that proximal and distal CRC evolve by different genetic pathways and that these pathways are influenced by sex-related factors. Their results, analyzed by statistical models, pointed to hormonal mechanisms with important clinical implications. They found that presence of TP 53 mutations was dependent on tumour location only, with a positive association to cancers occurring distally $(p=0.002)$. Microsatellite instability was found almost exclusively in proximal colon cancers.

Stigliano et. al. (2008) compared a cohort of 40 HNPCC cases with 573 sporadic CRC cases in the period 1970-1993. Median age of diagnosis was 46. 8 years in HNPCC cases and 61 years in sporadic CRC cases. $85 \%$ had right sided lesion in HNPCC group as opposed to $57 \%$ in sporadic cancer group.

Slattery et. al. (1996) studied age, sex and tumour sub-site distribution in 1709 CRC patients from three geographic areas in the USA. Approximately $50 \%$ of CRC in men and greater than $50 \%$ of CRC in women were in the proximal segment of the colon. Men who were diagnosed prior to age 50 and both men and women diagnosed at age 70 or older had predominantly proximal cancers. People with proximal cancers and those diagnosed prior to age 50 were likely to have more advanced disease. In general, both men and women had more proximal cancers with advancing age, which were associated with more advanced disease.

Ionov et. al. (1993) showed that $12 \%$ of CRC patients carried ubiquitous somatic deletions in poly (dA. dT) sequences and other simple repeats. Tumours with these mutations showed distinctive genotypic and phenotypic features. Patients with these deletions showed a predominance of right sided tumours while those without deletions had a predominance of left sided lesions.

Thibodeau et. al. (1993)studied the association of microsatellite alterations with preference for tumour subsite. All four sites of alteration studied showed a dramatic change in preference from distal to proximal colon in the mutated form (typical values: proximal/distal; $(26,49),(11,1$ in the mutated form) $)$.

Fancher et. al. (2011) studied 45 young patients, 20 males and 25 females,mean age 43. 6 years, in the USA and found preference for left sided lesions in females (16/8)and a preference for right sided lesions $(12 / 10)$ in men $(p=0$. 35; small sample size);right sided cancers had a higher stage at presentation. 
Kaw et. al. (2002) studied 1277 Filipino patients of whom $218(17 \%)$ were < 40 years, a mean age of 31.3 years. Cancers of the right colon were noted to be more common in females (55\%)and rectal tumours were seen more frequently in males $(55 \%$; $=0$. 014), but when analysed in relation to age, right colon cancers were actually more common in men $<40$ years of age $(p=0.013)$;the incidence in women was higher only above the age of 50 years. The proportion of CRCs located on the right side was $28 \%$ for $<40$ years patients and $20 \%$ for the $40+$ group. On the other hand, left colon cancers were seen in $30 \%$ of the older age group compared with $18 \%$ in the younger population $(p=0.001)$. For rectal cancer, there was no significant difference in proportion between the young and the old $(p=0.414)$.

Elsaleh et. al. (2000) in an older patient group (mean age 66. $7 \pm 12.9$ years) in Australia reported that MSI positive tumours were slightly more frequent in women than in men (10 vs $7 \%$ ). Right sided tumours were more frequently MSI positive than left sided tumours (20 vs $1 \%$ ). Men with right sided tumours benefited from chemotherapy (37 vs $12 \%$ ) but men with left sided tumours did not.

Mahdavinia et. al. (2005), Fazeli et. al. (2007) and Malekzadeh et. al (2009) found that in Iranian patients with positive family history of CRC, the most frequently affected site of colon was the right side. Malekzadeh et. al. (2009) found that MSI was more frequent in early-onset patients and in proximal tumours. They reported that proximal and distal tumours harbor different p53 mutational spectra;distal CRCs showed a higher frequency of $\mathrm{G}$ to $\mathrm{A}$ transitions at $\mathrm{CpG}$ whereas $\mathrm{G}$ to $\mathrm{A}$ transitions at non-CpGs were more frequent in proximal tumours. Fazeli et. al. (2007) found that $62.5 \%$ of patients with proximal colon tumours were males.

Nelson et. al. (1997) and Saltzstein et. al. (1997) showed that there was an increase in the relative proportion of proximal colon cancers with increasing age 'a shift to the right'. Thus with increasing age, full length colonoscopy will be a better screening tool. The exact age at which the shift occurs will vary with gender and ethnicity. There is a predominance of African-Americans amongst those at risk for proximal colon carcinoma and predominance of white males amongst those at risk for distal CRC.

Goh et. al. (2005) in a study of different races in Malaysia observed that demographic differences between Asia and the West may exist. No difference in anatomic distribution was found in Malay, Chinese and Indian races. They noted that in general CRC tends to be located distally in areas with a lower incidence of disease (parts of Asia) and migrated proximally with increasing incidence, as in Japan or Korea. They suggested that this may be related to a decrease in rectal cancer and an increasing proportion of elderly patients in the population. Young patients had a higher probability of having distal lesions as compared to the older patients.

Qing et. al. (2003) in a comparative study on Chinese and American patients, noted that the proportion of left sided lesions in Oriental patients (74\%) was significantly higher than that in Whites $(63.7 \%)$ and that rectal cancers were significantly more common among Orientals $(\mathrm{p}<0.001)$.

$\mathrm{O}^{\prime}$ Connell et. al. (2004a) in their review quoted average values of subsite location in $<40$ years young patients as follows: ascending $22 \%$, transverse $11 \%$, descending colon $13 \%$, rectum and sigmoid (including rectosigmoid junction) 54\%,a dominance of left sided tumour in the young.

We summarize reports on preference for tumour sub-site from different countries in Table 4 . Some of these are cited in Table 1-3 where patient groups are detailed. The others are detailed in Table 4. 


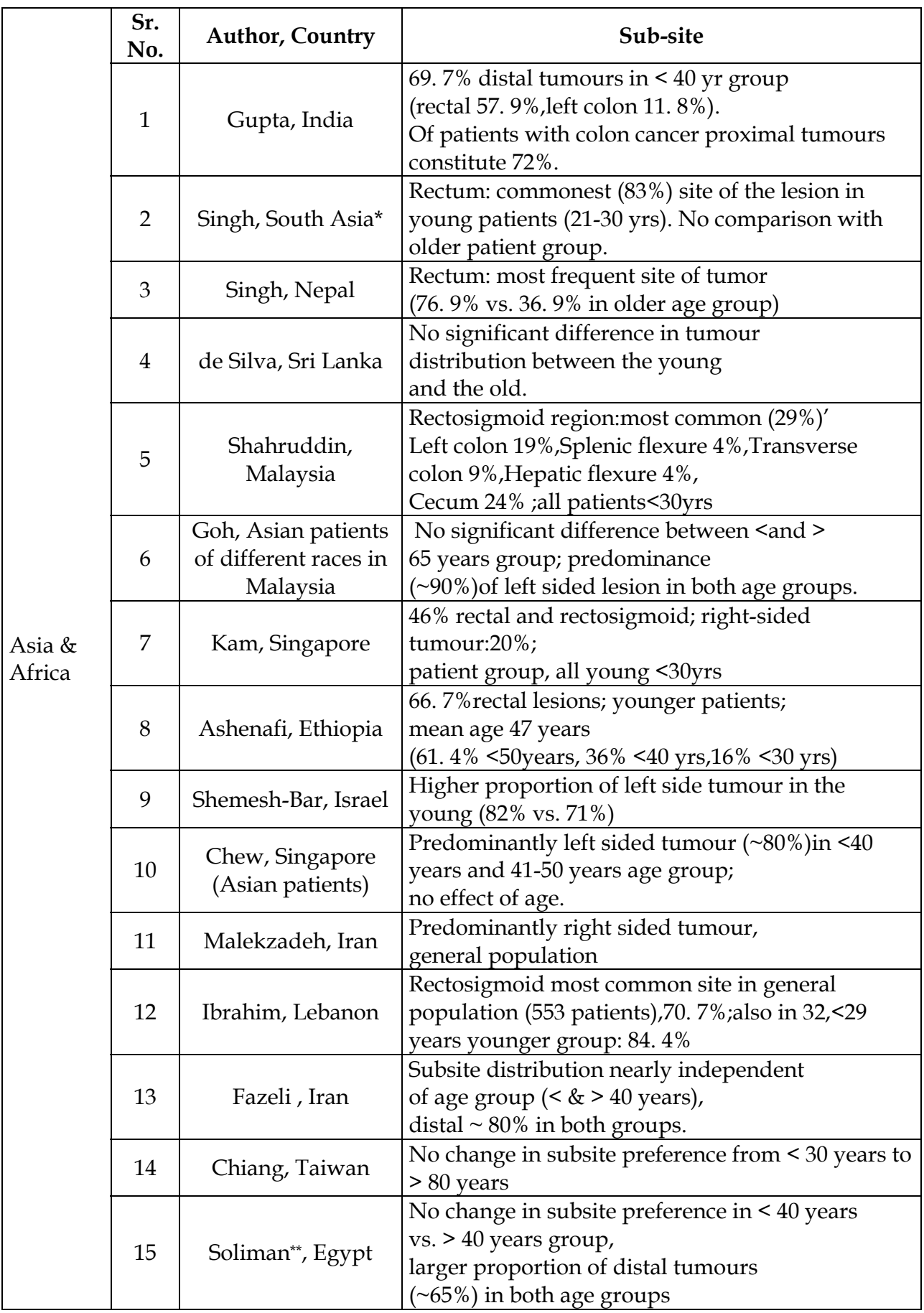




\begin{tabular}{|c|c|c|c|}
\hline \multirow{12}{*}{ U.S. A. } & $\begin{array}{l}\text { Sr. } \\
\text { No. }\end{array}$ & Author, Country & Sub-site \\
\hline & 16 & Bedekian, USA & $\begin{array}{l}\text { Increase in primary lesions in the right colon with } \\
\text { increasing age at diagnosis; }<40 \text { yrs group } \\
\text { compared with general population. }\end{array}$ \\
\hline & 17 & Cozart, USA & $\begin{array}{l}\text { Dominance of left sided lesions } \\
(12 \text { right colon, } 24 \text { left colon, } 11 \text { rectum) and left } \\
\text { colon amongst colon cancer patients; study group } \\
\text { comprises of only young patients }<30 y r s \text {. No } \\
\text { comparison with older group. }\end{array}$ \\
\hline & 18 & $\begin{array}{l}\text { Nelson, USA \& } \\
\text { Saltzstein, USA }\end{array}$ & $\begin{array}{l}\text { Significant shift to right sided lesion with } \\
\text { increasing age; }<50 \text { vs. }>50 \text { yrs. }\end{array}$ \\
\hline & 19 & Slattery, USA & $\begin{array}{l}\text { Proximal cancers more frequent }(>50 \%) \text { in men }<50 \\
\text { years and in both men and women }>70 \\
\text { years(details in text). }\end{array}$ \\
\hline & 20 & Fairley, USA & $\begin{array}{l}\text { Rectal cancers more frequent in }<50 \text { yrs group } \\
(37 \% \text { vs. } 26 \%) \text {; proximal colon cancer more } \\
\text { frequent in }>50 \text { age group ( } 42.6 \% \text { vs. } 32 . \\
1 \%) \text {,remaining }<50 \% \text { in both groups. }\end{array}$ \\
\hline & 21 & Lichtman, USA & $\begin{array}{l}\text { Older patients: more transverse/right sided } \\
\text { lesions }(\mathrm{p}=0.003) .138 \text { patients;mean age of } \\
\text { patients with different sites of tumour: } \\
\text { Right colon } 72 \text { yrs,left colon } 66.1 \text { yrs, } \\
\text { rectum } 61.6 \text { yrs }\end{array}$ \\
\hline & 22 & Karsten, USA & $\begin{array}{l}\text { Right sided lesion more frequent }(44 \%) \text { in young } \\
\text { compared to } 21 \% \text { in older group, } \mathrm{p}=0.004 \text {. }\end{array}$ \\
\hline & 23 & Minardi, USA & $\begin{array}{l}\text { Tumours evenly distributed in colon and rectum } \\
\text { (under- } 40 \text { group). } \\
\text { Older group not compared. }\end{array}$ \\
\hline & 24 & $\begin{array}{c}\text { O'Connella }^{\prime} \\
\text { (International Review) }\end{array}$ & $\begin{array}{l}\text { Rectum and sigmoid colon most frequent sites } \\
(54 \%) \text { in the young }<40 \text { yrs patient group. }\end{array}$ \\
\hline & 25 & Dozois, USA & $\begin{array}{l}\text { Predominantly rectum }(49.1 \%) \text { or left colon } \\
(29.1 \%) \text { than proximal colon }(21.9 \%) . \\
\text { All young patients }<50 \text { yrs. } \\
\text { No comparison with older patient group. }\end{array}$ \\
\hline & 26 & Behbehani, USA & $\begin{array}{l}\text { Colon: Right } 21 \%, \text { Transverse } 21 \% \text {, Left } 14 \% \\
\text { Sigmoid \& Rectum } 44 \% \text { in the }<40 \text { yrs group; these } \\
\text { figures are } 34 \%, 4 \%, 8 \%, 54 \% \text { respectively in the } \\
\text { older group. }\end{array}$ \\
\hline \multirow[b]{2}{*}{ Europe } & 27 & Leff, UK & $\begin{array}{l}\text { Only } 12 \% \text { right-sided colon cancer, }<40 \text { yrs } \\
\text { patients, no comparison with older group. }\end{array}$ \\
\hline & 28 & Fante, Italy & $\begin{array}{l}\text { Majority of tumours in left colon and rectum in the } \\
\text { whole patient group }<40-55 \text { years. } \\
\text { Right colon: } 37 \% \text { in }<40 \text { years, } 18 \% \text { in } 41-50 \text { years, } \\
14 \% \text { in } 51-55 \text { years group. }\end{array}$ \\
\hline
\end{tabular}

*Singh et. al. 1984; **Soliman et. al. (1997)

Table 4. Tumour Sub-site in the young in different countries 
In some of these papers, (Sr. No. 1, 2, 5, 7, 8, 10, 17, 23-25, 27), a preference for distal lesions in the young patients were cited, but were not compared with the older patient groups. In some others (Sr. No. 3, 9, 12, 16, 18-21) this comparison was made and a change in preference for tumour sub-site with increasing age was noticed. Shemesh-Bar et.al. (2010, Sr. No. 9) and Ibrahim et. al. (1986, Sr. No. 12) found that although left sided lesions formed the majority of tumours, their proportion decreased in the older group. Singh et. al (2002a, Sr. No. 3) and Fairley et. al. (2006, Sr. No. 20)found that the proportion of rectal cancers decreased with increasing age. In several reports preference for right sided lesions showed an increase with increasing age (Sr. No. 16, 18, 20-21). Slattery et. al. (1996, Sr. No. 19)reported an increase in proportion of proximal tumours with increasing age for women, exceeding $50 \%(62.3 \%)$, only in the age group $70-79$ years. Amongst men, proportion of proximal tumours exceeded $50 \%$ in the $<50$ yr groups (62. 5\%, 30-39 yrs; $51.1 \%, 40-49$ yrs), falls below $50 \%$ in the 50-59 and 60-69 yrs groups and then rises again to $54 \%$ in the $70-79$ yrs group. A decrease in proximal tumours with increasing age was reported by Karsten et. al. (2008, Sr. No. 22) and Fante et. al. (1997, Sr. No. 28). Both studies reported a dominance of distal tumours in different age groups (two in Sr. No. 22, three in Sr. No. 28), but proximal tumours decreased with increasing age. In a few papers (Sr. No 4, 6, 10, 13-15, 26) sub-site preference was found not to depend on age. Fazeli et.al. (2007, Sr. No. 13) reported that $80 \%$ of the tumours were distal in the young ( $<40$ years) and also in the older age group. In these reports which did not find any effect of age on subsite preference, distal tumours were $>50 \%$ in the young and in the older group. A preference for proximal tumours in a population of colon cancer patients were reported in several papers (Sr. No. 11 and Mahdavinia et. al. (2005) in general population of colon cancer patients from Iran, where incidence is lower than in the West and in Sr. No. 1 in young colon cancer patients $<40$ years in India). Cozart et. al. (1993, Sr. No. 17) found tumour sub-site preference for left colon (24/12) in a small population of colon cancer patients; Dozois et. al. (2005, Sr. No 25) found the same preference in a much larger (1025 patients) young ( $<50 \mathrm{yrs})$ population. We cite several prospective reports on change in relative preference of tumour sub-site over a long time period. Fazeli et. al. (2007, Sr. No. 13) reported that the nearly equal preference for distal tumours $(\sim 80 \%)$ in the $<40$ years and in the $>40$ years group in Iran, remained unchanged for two decades (1970-80, 1990-2000). In contrast, it was reported in a study on patients from New Zealand, in the period 1974-83 (Jass 1991), that the incidence of right colon cancers remained stable in younger patients ( $<50$ years), that in older patients showed an increase and a marked reduction in left colon and rectal colon cancer in $<50$ years group was observed. An increase in proximal CRC relative to distal tumours was reported in another retrospective study in the period 1940-79 in the US (Beart et. al. 1983).

\section{4. de novo CRC in Asia}

The problem arising from inability to detect cancer early because of hospital infrastructure and relative lack of awareness of the disease may not be the only problem peculiar to the developing world in Asia and Africa. Sung et. al. (2005) pointed out that non-polypoidal (flat or depressed) lesions and colorectal neoplasm arising without preceding adenoma (de novo cancer) seemed to be more common in Asian than in other populations. Although most cases of colorectal cancer are thought to arise from a sequence of adenoma to carcinoma, evidence from Asia, in particular Japan suggests another mechanism. Clinicopathological studies have shown that there are two groups of colorectal cancer, 
polypoid and non-polypoid (superficial) tumours. The latter are flat lesions with a raised or depressed surface. Since these tumours are small $(<1 \mathrm{~cm}$ in diameter) and there are no adenomatous elements in their vicinity, they were proposed not to have originated from any precursor lesion and were termed de-novo carcinomas. These non-polypoid tumours are less likely to have K-ras mutations than are CRC arising from the adenoma-carcinoma sequence. Non-polypoid tumours of the colorectal regions tend to reach deeper layers of the intestinal wall in the early stage of the disease and with a higher degree of dysplasia. They are therefore more invasive than the polypoid adenomas (Sung et. al., 2005). Reports on de novo cancer have been published from Japan (Goto et. al 2004) and from Taiwan (Chen et. al 2003). About one-third of CRC patients in both countries have de-novo cancer. One study from UK also reported this feature (Rembacken et. al., 2000). Whether this feature is unique to Asia or whether it shows any preference for the younger or the older group of patients is not reported. Because of their flat appearance they are harder to identify by conventional colonoscopy. Chromoendoscopy and the use of magnifying colonoscopy may be necessary. The absence of polypoid growth preceding malignancy has posed difficulties in screening for early CRC by radiological imaging or even endoscopic techniques.

\section{Early onset CRC and genetics}

Colorectal tumours provide an excellent model system for understanding the molecular events that control the process of initiation and progression of human tumours. Rate of random mutational events alone cannot account for the number of genetic alterations found in most human cancers and it has been suggested that destabilization of the genome may be a prerequisite early in carcinogenesis. In CRC there are two separate destabilizing pathways. The more common involves chromosomal instability (CNI). The second mutational pathway in CRC displays increased rate of intragenic mutation characterized by generalized instability in microsatellites (MSI). Defects in mismatch repair genes (MMR) lead to high frequency MSI in CRC. National Cancer Institute definitions of MSI-L (L=low), MSI-H ( $\mathrm{H}=$ high) and MSS (microsatellite stable) in CRC are given in Boland et. al. (1998). A recently recognized molecular alteration found frequently in MSI cancers is the CpG island methylator phenotype (CIMP). Colon cancer is usually observed in one of three specific patterns: sporadic, inherited or familial. Fewer than $10 \%$ of patients have an inherited predisposition to colon cancer. Sporadic cancer is common in persons older than 50 years of age, probably as a result of dietary and environmental factors as well as normal aging. Patients with inherited disease have CRC at a younger age, 10-20 years earlier than general population and are of interest in this essay. The area of hereditary CRC has been reviewed by Lynch and de la Chapelle (2003)and earlier by Lynch et. al (1991). Different aspects of molecular genetics of CRC have been discussed in this series (Ewart Toland, 2012) and elsewhere (Fearon and Volgenstein 1990; Loeb 1994; Jass 1995; Lynch 1996; Baba 1997; Gryfe et. al. 1997; Lengauer et. al. 1998; Lynch and Smyrk 1998; Lynch and de la Chapelle 1999; Yang 1999; Potter 1999; Jass et. al. 2002; Calvert and Frucht 2002; Zbuk 2009). In this section we discuss several recent papers which highlight the difference in genetic characteristics of younger CRC patients and those of the older group.

Morris et. al. (2007) showed that the incidence of tumours with microsattelite instability was significantly higher in patients aged $\leq 40$ years, $18.3 \%$ compared to $6.6 \%$ in those aged $41-$ 60 yrs $(p<0.0001)$. TP53 mutations were also more frequent $(p=0.002)$. However K-ras mutations were less common $(p=0$. 0001) when comparing the same age groups. They 
concluded that major age related differences in the clinical and molecular features of CRC exist.

Farrington et. al. (1998) pointed out that germ-line mutations in DNA mismatch-repair (MMR) genes impart a markedly elevated cancer risk, often presenting as autosomal dominant HNPCC. Not all gene carriers have a family history. Young probands with early onset CRC irrespective of family history were genetically tested and it was found that an appreciable proportion of young colon cancer probands carry a germline mutation in a DNA MMR gene.

Losi et. al. (2005) evaluated clinical features and molecular pathways, chromosomal instability (CNI) and MSI in early onset CRC. Of 71 patients ( $<45$ years), 14 showed both MSI and altered expressions of MMR proteins. In the 57 MSI -negative (-) lesions, altered expression of APC, $\beta$-catenin and p53 genes were found more frequently than in MSIpositive $(+)$ tumours. 7/14 MSI $(+)$ tumours were associated with clinical features of HNPCC and in all but one, constitutional mutations in MLH-1 and MSH-2 genes could be detected. The same mutations were found in other family members. Involvement of chromosomal instability was demonstrated in a majority of early onset CRC.

Chan et. al. (1999)studied 59 Chinese patients $<45$ yrs and 58, >45 yrs in Hong Kong. The incidence of MSI-H varied statistically significantly with age, being observed in $>60 \%$ of those $<31$ years at diagnosis and in $<15 \%$ of those $\geq 46$ years. More than $80 \%$ of Chinese CRC patients $<31$ years had germline mutations in MMR genes. In a novel case, mutation in hMSH-6 was present but MSI was absent.

Ho et. al. (2000) in a study on 124 young $(<50 \mathrm{yrs})$ Hong Kong Chinese CRC patients concluded that MSI occurs in a significant proportion of the subjects. Young age at CRC diagnosis, proximal tumour location, increasing number of first degree relatives with CRC and a personal history of metachronous cancer were independent predictors of MSI status in the patient group. In patients $<30$ years, MSI tumours were more likely to be located in distal large bowel. In a proportion of patients with MSI tumours, germline mutation in the two MMR genes hMSH2 and hMLH1 was identified. The authors opined that this observation suggests a differential activity of the MMR pathway in colorectal carcinogenesis in different age groups. They observed that the inconsistency between MSI-H and a family history in the early onset patients deserves further attention.

Liang et. al. (2003) studied 138 below-40 CRC patients and 339 patients who were $60+$. They found a higher percentage of normal p53 expression $(61.1$ vs. $46.8 \%, \mathrm{p}=0.023)$ and high frequency microsatellite instability (MSI-H) ( 29.4 vs. $6.3 \% \mathrm{p}<0.001)$ in the young. The family history of the two groups was similar.

Durno et. al. $(2005,2006)$ found evidence of MSI in $73 \%$ cancers from individuals in $9-24$ years of age, $50 \%$ of whom had features of HNPCC. Other reports found MSI in $46 \%$ of under- 21 patients with only $1 / 3$ having a clear family history.

Sanchez et. al. (2009) performed a molecular classification of CRC based on microsattellite instability (MSI), CpG-island methylator phenotype (CIMP) and mutations in the K-ras and BRAF oncogenes. There were four classes, combinations of MSI-H and MSS with CIMP-H or CIMP (-). $69.8 \%$ of tumours (391 subjects) were MSS-CIMP(-) and less likely to be poorly differentiated $(p=0.009)$. CIMP-H tumours were more common in older patients $(p<0.001)$. MSI-H/CIMP-H tumours had a high frequency of BRAF mutation and a low rate of K-ras mutation, the opposite was true for MSS-CIMP(-) tumours $(\mathrm{p}<0.001)$. The four molecular phenotypes tended towards divergent survival. MSI-H cancers were associated with better disease free survival. 
Alsop et. al. (2006) investigated association of young age in below-45 patients with somatic mutation of K-ras gene, a common event in CRC tumorigenesis. The role of these mutations was found to be comparatively minor in the younger group, in contrast to its significant role in CRC of older age of onset.

Soliman et. al. (2001) compared molecular pathology of CRC in Egyptian ( $44 \%<40$ years) and Western patients. They found MSI-H carcinoma in $17 \%(2 / 12)$ of under-40 and $46 \%$ $(12 / 26)$ of $40+$ Egyptian patients; K-ras gene mutation in $0 \%(0 / 18)$ of under-40 group and in $17 \%(5 / 29)$ of $40+$ group; p-53 overexpression in $57 \%(13 / 23)$ of under-40 group and $39 \%$ $(13 / 33)$ of $40+$ group. These data show that molecular pathology of CRC in young Egyptians differed from that in the old; in particular, K-ras mutation played a distinctly minor role in the younger group. Unique differences in molecular pathology of CRC between the Egyptian and Western patients were also discussed.

Breivik et. al. (1997) found that the presence of K-ras mutation was dependent on age and gender of the patient, with an especially low frequency amongst young males. Microsatellite instability was rare in tumours with K-ras and TP53 mutations.

Berg et. al. (2010) focused on the somatic tumour development in young patients with no known inherited syndromes. They studied mutations in oncogenes K-ras, BRAF, PIK3CA and the tumour suppressor gene PTEN and in TP53, in three age groups in 181 patients (45, $<50$ yrs; 67, 51-70 yrs; 69, >70 yrs). Distinct genetic differences were found in tumours in the young and the elderly patients, who were comparable for known clinical and pathological variables. This result indicated that young patients had a different genetic risk profile for CRC development than older patients. Clinical implications of these differences were discussed by the authors. The total gene mutation index was lowest in tumours from the younger patients. In contrast the genome complexity assessed as copy number aberrations was highest in tumours from the youngest patients.

Casper et. al. (1994) showed in a study on 225 FAP patients that deletion of 5 base pairs at codon 1309 within exon 15 (the most common mutation) was identified in 20 families. Other mutations within exons 7-15 were found in 49 families. The 1309 mutation leads to development of colonic polyps at a younger age thus giving rise to an earlier malignant transformation. In patients with 5 base pair deletion at codon 1309, gastrointestinal symptoms and death from CRC occurred about 10 years earlier than in patients with other mutations.

Khan et. al. (2008) studied 35 patients with CRC diagnosed at $<30$ years age. They found no mutations in exons 4-10 of the p53 gene. The frequencies of polymorphism in p53 and in MDM2SNP309 did not differ from rates previously reported for normal control populations and no polymorphism in either gene could be associated with early onset CRC.

Ahmed et. al. (2005) reported a study on 363 CRC patients of whom 18 were of Bangladeshi origin. $22 \%$ of Bangladeshi patients presented with a locally advanced or a metastatic CRC, whereas the same figure for non-Bangladeshi patients was $11 \%$. Sixty one percent of the Bangladeshi patients were below 40 years of age and did not report any family history. Microarray profiling between these two groups demonstrated 1203 differentially expressed genes $(\mathrm{p}<0$. 05). The patient groups studied by Nath et. al. (2005) and by our group, (Gupta et. al. 2010) (Table 3) and by Pal (2006) belong predominantly to West Bengal in India, which is adjacent to Bangladesh. These studies reported dominance of younger patients in their study groups, advanced disease stage and aggressive tumour characteristics.

Liu et. al. (1995) studied the prevalence of DNA replication errors (RER) associated with genetic instability in relation to age among patients without HNPCC. RER was found in 
cancers of several different types, particularly in HNPCC. CRC in majority of $<35$ years group (58\% of 31 patients) exhibited instability whereas CRC in $>35$ years group uncommonly did (12\% of 158). In 12 of $<35$ years group, instability was evaluated for alterations of MMR genes and in 5, it was found to harbor germline mutations. These data suggested that the mechanisms underlying tumour development in young CRC patients differ from those in most older patients.

Lin et. al. (2010) showed in a study cohort of 950 patients (2000-2005) that carcinogenic effects of Western lifestyle might be mediated via insulin-like growth factor-1 (IGF-1). IGF-1 is a peptide growth factor that promotes cell proliferation and inhibits apoptosis. Both in vitro and in vivo studies suggested that IGF-1 could promote CRC growth. Further, circulating levels of IGF-1 were associated with various cancers including CRC. It was shown that genetic variation controls variability of circulating IGF-1. The expression of IGF-1 was reported to vary in different ethnicities. In turn it was speculated that polymorphisms of the genes involved in the IGF axis might affect IGF-1 expression and possible cancer risk. The age at onset of CRC varied considerably. Extreme age at the CRC onset, very young or very old seemed to be associated with different carcinogenesis. It was shown that some genetic polymorphism affects age of onset of cancers. For example IGF-1 polymorphism plays a significant role in affecting disease onset in Lynch syndrome. These authors showed that older patients have a higher frequency of AA genotype of IGF-1 ($2995 \mathrm{C} / \mathrm{A})$, significantly higher (12. 7\%) than that in younger patients (4. 2\%). Mucinous differentiation, but not other clinicopathological factors was associated with the CA /AA genotype of IGF-1. The authors concluded that the genotype of the IGF-1 promoter was different in young CRC patients compared to older CRC patients and that IGF-1 SNP was associated with mucinous adenocarcinoma.

Yantis et. al. (2009) provided data to show that post translational regulation of mRNA and subsequent protein expression may be particularly important to the development of CRC in young patients. They compared 24 patients $<40$ yrs of age with 45 patients $\geq 40$ yrs of age, who served as controls. Cases were evaluated for clinical risk factors of malignancy and pathologic feature predictive of outcome. More aggressive features in tumours of young patients, namely more frequent lymphovascular (81\%) and venous (48\%) invasion, an infiltrative growth pattern (81\%) were reported. Significantly increased expression of miR21, miR-20a, miR-145, miR-181b, and miR-203 was noted in the younger group.

\section{Predisposing factors}

Family history of CRC at a young age is a significant risk factor. Johns and Houlston (2001) performed a meta-analysis of 27 case-control and cohort studies of colorectal cancer risk and found that a family history of one affected first degree relative diagnosed before the age of 45 carried a 3.87 fold ( $95 \%$ confidence interval 2. $40-6.22$ ) increased risk for the disease. Fuchs et. al. (1994) concluded that a family history of CRC is associated with an increased risk of disease, especially amongst the young. The relative risk factor of an under- 45 yrs person with one or more affected first degree relative as compared with those without a family history was 3. St. John et. al. (1993) performed a case-control study of relatives of CRC patients and of matched control patients. They concluded that first degree relatives of patients with CRC have an increased risk of colorectal cancer. The risk was greater if diagnosed at an early age and when other first degree relatives were affected. Winawer et. al. (1996) observed that siblings and parents of patients with adenomatous polyps were at 
an increased risk for CRC particularly when adenoma was diagnosed at $<60$ yrs age. Despite limited accuracy and compliance, family history is still the most easily obtainable risk factor for colorectal cancer.

Deficiency in host response to carcinogenesis is less easily recognized and treated. A personal history of other cancers, especially chronic immunosensitive cancers such as melanoma, if occurring at a young age, may indicate an increased susceptibility to CRC. Chronic immune suppression or clinical suggestions of impaired immunity may also mean the same.

FAP and HNPCC patients have a lifetime risk of 100 and 80 percent respectively, of developing CRC. In FAP, the affected persons develop hundreds to thousands of colonic polyps. Although the rate of transition to cancer is slow, the vast number of polyps virtually assures colon cancer development at a young age. Average age of developing cancer is 39 years, with $7 \%$ diagnosed by the age of 20 and $15 \%$ by 25 . In HNPCC, the affected persons have a very high risk for CRC but do not develop the hundreds of polyps seen in FAP. These polyps are very likely to make a transition to cancer. Although sporadic colon cancer usually arises in colon polyps after a 5-10 years period of growth and transformation, in HNPCC this progression can occur within $1-2$ years. HNPCC occurs at a relatively young age, median $42-45$ years, with $35 \%-40 \%$ diagnosed before 40 years of age. The proportion of HNPCC or familial colorectal cancer among all CRC varies by country from $1-10 \%$ with a median of 2-5\% (Mecklin and Ponz de Leon 1994). HNPCC has been reported from many different populations, Europeans, white and Indian Americans, Asians, Australasians, South Americans and Egyptians (Sarroca et. al. 1978; Bamezai et. al. 1984; Ushio 1985; Lynch et. al. 1985; Mecklin 1987; Vasen et. al. 1990; Mecklin and Jarvinen 1991; Jass and Stewart 1992; Soliman et. al. 1998).

Ulcerative colitis (UC) is another important predisposing factor. The most important risk factors for development of CRC in UC patients are prolonged duration of disease, pancolonic disease, continuously active disease and severity of inflammation. Eaden et. al. (2001) performed a meta-analysis of the risk of CRC in UC. 116 of 194 reported studies were included in this analysis. Overall prevalence of CRC in UC patients was 3. 7\%. The risk of CRC in UC patients was determined by decade of disease and a non significant increase in risk over time was observed.

\section{Prognosis and survival of young patients}

Opinion on the issue of survival of younger patients is not unanimous. We have divided literature reports on this issue, pre-2000 and post-2000, in two separate sections. The reports in which prognosis for the young is shown to be poorer and the ones in which they are not so, are separately grouped.

Pre-2000, poor prognosis: Moore et. al. (1984) concluded that poorer survival in younger ( $<40$ years) patients was a result of an inherently more virulent lesion, a conclusion supported by a greater incidence of mucinous tumours, an indicator of poor prognosis and a higher incidence of advanced disease, especially in the second and third decades. They did not find delay in diagnosis as an important factor in determination of survival. Adkins et. al. (1987) ascribed poorer prognosis in the young (<35 years) to unfavourable histological features of the tumours and advanced disease at the time of presentation in these patients. Of 45 under-35 patients, 19 patients with poorly differentiated tumours survived for an average of 1 year, whereas 19 with well or moderately differentiated tumours survived for 
an average of 4.5 years. Those few patients who presented early in the course of their disease responded well to radical resection. Okuno et. al. (1987) reported frequent occurrence of mucinous carcinoma, lymph node involvement and advanced stage according to Dukes' classification in the younger group (<39 years). The overall survival rate was poorer in the younger group ( $41 \%$ vs. $55.9 \%)$, whereas the difference between the two groups in rates of curative resection was not statistically significant.

Pre-2000, favourable prognosis: Howard et. al. (1975) found that younger patients had a greater frequency of advanced signs, later stages of cancer and mucoid carcinoma, but when compared by clinical stage, they did as well or better than older patients. 5-year survival rates were $31 \%$ in $<40$ years group and $32 \%$ in $>40$ years group. Clinical staging was the most important prognostic factor irrespective of age. No inherent difference was found in the virulence of cancer in the young, survival rate being essentially the same. Adloff et. al. (1986) in a paper published much later reached identical conclusion. Walton et. al. (1976) in a study on 70 under-40 patients reported that survival time was shorter in patients with mucinous and anaplastic tumours and their incidences increased in this age group. Overall survival rates, however, did not significantly depend on age. Early diagnosis and prompt aggressive surgical treatment produced survival equivalent to that in patients of other age groups. Scarpa et. al. (1976) in a study on 47 adults in the age group 20-40 years found smaller tumours and depth of invasion as important prognostic factors but tumour grade had no correlation with survival. They concluded that there was no difference in survival rate between the young and the old. Bulow (1980) found, in an extensive study spread over 25 years (951<40 patients, all $<40$ patients in Denmark in the period 1943-1967) that stage according to Dukes' classification and presence of intestinal obstruction and/or perforation and not age, determined prognosis. Ahlberg et. al. (1980) in a study group of 27 patients, aged <30 years, in 1969-70 in Scandinavia, concluded that prognosis was good, if predisposing factors were absent $(9 / 15$ survived 5 years), but not so otherwise. Ohman (1982) in a study group of 1061 patients, of whom 48 were below 40, in Sweden reported a five year survival rate in the overall population and in curable cases. Both rates were equal in the two age groups. Age factor had no impact. Five year survival was $100 \%$ in stage A, $50 \%$ in B, 33\% in C. Proportion of Dukes' A lesion was equal in the two groups; there were fewer B and more $C$ lesions amongst the young. Survival was not altered if ulcerative colitis was superimposed on carcinoma. Beckman et. al. (1984) studied 69 patients, 20-39 years and reported good prognosis. Neither age, sex, tumour size, location, mere presence of lymph node metastases, depth of tumour invasion nor predisposing disease of the colon was a strong prognostic factor. Metastases of six or more lymph nodes and distant spread of the tumour at the time of initial surgery were ominous findings; so was mucinous carcinoma, a relatively frequent occurrence. Jarvinen and Turunen (1984) in a study on 249 under-40 year patients between 1970 and 1979 found no difference in their 5 year survival rate from that of the general population. A premalignant condition was more common as age decreased. Family cancer syndrome, FAP and other predisposing diseases were observed in a significant proportion of study group. It was suggested that more emphasis should be placed on identification, family screening and treatment of conditions predisposing to colorectal cancer. LaQuaglia et. al. (1992) analysed their experience with 29 histologically verified cases of whom 20 were resected for cure. The predictors for survival were resectability, regional nodal involvement, depth of invasion, grade (Signet ring $(45 \%)$ or anaplastic lesions (24\%) were considered high grade) and interval from symptom onset to diagnosis. Median age at diagnosis was 19 years (10-21 years), median survival was 16 
months, that for those undergoing complete resection was 33 months. In those undergoing resection for cure, tumour grade, regional nodal involvement and depth of invasion were the only factors that affected prognosis. Hidalgo (1995) in Spain studied 26, under-45 CRC patients (17. $2 \%$ of the whole group) whose potential risk factors were no different from those of the general population. Clinical presentation, tumour site and Dukes' stage were similar in the younger group and in the general population, but morbidity, mortality and post operative complications were lower. There were no differences in resection or survival rates. Chung et.al. (1998) in a study on 101 under 40 patients and 2064 older patients found no difference in tumour characteristics, Dukes' stage and overall 5 year survival, but reported a higher adjusted hazard ratio and adverse outcome in the $<40$ years group compared to 40-59 years group. They noted that a significant family history and predisposing conditions in the young warrants aggressive screening, surveillance and treatment. Heys et. al. (1994) in a review reported histological evaluations of the cancers in the younger age group patients and found that approximately four times as many tumours were of the mucinous type. This was associated with an increased risk of local recurrence. Dukes' staging and vascular invasion by tumour were prognostic indicators for overall patient survival. However survival rates for young patients with CRC were comparable to those of older patients, when equivalent Dukes' stage was considered.

Post-2000, favourable prognosis: O'Connell et. al. $\left(2004^{\mathrm{b}}\right)$ used SEER (Surveillance, Epidemiology and End Results) database in the period 1991-1999 in the USA (1334 younger patients, $20-40$ years; 46,457 older patients $60-80$ years) to conclude that 5 -year stage-specific survival was similar for stage I and III patients and better for younger patients in stage II and IV $(p<0.01)$. The same patient group showed later stage (more of stage III and IV) and higher grade tumours for younger patients. The authors noted that their population-based finding contradicts earlier single institution reports. Stigliano et. al. (2008) compared a cohort of 40 HNPCC cases with 573 sporadic CRC cases in the period 1970-1993. Median age of diagnosis was 46. 8 years in HNPCC cases and 61 years in sporadic CRC cases. Early stage cancer (Dukes' A \& B) was 70\% in HNPCC group and $61.6 \%$ in sporadic group. The crude 5-year cumulative survival for primary CRC was 94. $2 \%$ in HNPCC vs. $75.3 \%$ in sporadic cancer patients $(p<0.0001)$. The influence of age on prognosis is apparent.

Berg et. al. (2010) studied 181 patients (45, < $50 \mathrm{yr} ; 67$ (51-70 yr); 69, > $70 \mathrm{yr}$ ) and found no difference in survival while comparing age groups, even when adjustment for tumour stage at diagnosis had been made. Younger patients however presented at a more advanced disease stage (54, 46, and $36 \%$ in three groups). Tumour stage was the most powerful prognostic variable $(\mathrm{p}<0$. 001). Turkiewicz et.al. (2001) in a study spanning 29 years in Australia concluded that young patients with CRC had the potential to do just as well. The overall 5years survival among younger patients in Stage A and B (53\%) was found to be better than their counterparts in the older group. With influence of a family history of CRC being very apparent in this group, the authors conclude that emphasis must be on screening. Makela et. al. (2002) in a study of 102 under-50 patients in Finland over a 20 years period (1980-1999) concluded that young age is not a poor prognostic marker in colorectal cancer. Radical operation, venous invasion and tumour grade were good predictors of survival in patients below 50 years. Kam et.al. (2004) in a study in Singapore on 39 under-30 years patients inferred that age did not affect survival and recommended early endoscopy for all with persistent symptoms. They concluded that early diagnosis, radical resection and adjuvant therapy still form the cornerstone in management of colorectal cancer in this age group. Karsten et.al. 
(2008) in the USA performed a comparative study of two groups, $<40$ years and $>60$ years of age, ethnically diverse, between 1998 and 2005. Fifty one percent of 41 young patients were Hispanic. Young patients were more likely to have a family history. Aggressive nature of tumour in the young was noted, but operative intervention and survival was similar in the two groups. Tohme et. al. (2008) in a study of 325 patients, 13. $2 \%$ of whom were below 45 concluded that age by itself was not a significant prognostic factor. The independent prognostic factors were delay in consultation, which was more frequent in younger patients ( 29.7 vs. 18.6 weeks, $\mathrm{p}=0.01)$, positive family history in the young $(44.1 \%$ vs. $18.2 \%)$, right sided tumour and peritoneal carcinomatosis. Leff et. al. (2010) in a British study of $49,<40$ patients reported a 5 -year and overall survival of $58 \%$ and $46 \%$ respectively. They concluded that prognosis in the young was not worse than that for CRC in the population as a whole. Mitry et. al. (2001) reported, in both overall and stage for stage comparisons that patients below the age of 45 years had a better survival rate than older patients, mortality rate was lower in the younger group (2. $1 \%$ vs. $8.4 \%)$ although advanced stage presentation was more frequent and predisposing conditions were significantly higher in the below 45 group (11. 7 vs. $0.4 \%, \mathrm{p}<0.001$ ). Lin et. al. (2005) studied 45 histologically confirmed under- 40 patients, $90 \%$ of whom reported with advanced (C+D) stage, between 1992-2002 in Taiwan. They reported that disease stage was an important prognostic factor, 5 year survival in $\mathrm{B}, \mathrm{C}$ and D stage patients being 25,16 , and $0 \%$ respectively. Karnofsky performance status (KPS $\geq 70 \%$ ), lymph node involvement and preoperative LDH levels were major determinants of survival. Surgical resection and adjuvant chemotherapy improved survival of advanced stage patients, but the improvement achieved does reach the level of a patient who reports early. Liang et. al. (2003) reported that although the younger patients with colorectal cancer had more mucin producing (14. 7 vs. $4.7 \%, p<0.001)$ tumours and a more advanced tumour stage at presentation $(\mathrm{p}<0$. $001)$ than older patients, the operative mortality rate was lower ( 0.7 vs. $5 \%$ ) and cancer specific survival was similar $(\mathrm{p}<0.05)$ in stage I, II, III disease or better in stage IV disease (22-28 vs. 1217 months, $\mathrm{p}<0.001)$.

Post-2000, poor prognosis: Endreseth et. al. (2006) in a study on 2283 rectal cancer patients found overall 5-year survival to be $54 \%$ for patients younger than 40 years compared to $71-88 \%$ for the older patients $(p=0.029)$. Among those treated for cure, $56 \%$ of $<40$ group developed distant metastasis compared to $20-26 \%$ in the older group. Age younger than 40 years was a significant prognostic factor in this group and increased the risk of metastasis and death. A study from Nepal by Singh et. al. (2002a) reported a more aggressive disease in the younger group ( $<40$ years) and a significantly lower 2 years survival rate $(4 \%$ vs. $55 \%)$. Singh et. al. $\left(2002^{\mathrm{b}}\right)$ in a study on 18 under 40 patients in India found that the tumor was unresectable in 5 patients $(28 \%)$. Fourteen patients $(78 \%)$ had advanced cancer indicated by TNM stage III or IV disease. Among the 13 patients subjected to surgical treatment followed by adjuvant chemotherapy, only 3 had long term disease free survival beyond 2 years.

Prognosis and Genetics: There have been reports in the literature that suggest that the survival of MSI-H CRC patients is longer than that of patients with MSS CRC. This latter group constitutes the majority. In some studies however no survival advantage was detected and a National Cancer Institute workshop held in 1998 (Boland et. al. 1998) concluded that MSI had not been shown to be an independent predictor of prognosis (Gryfe et. al., 2000). We cite a number of mostly post-2000 papers that link prognosis to MSI tumour pathway. 
Gryfe et. al. (2000), in a study on 607 under-50 patients found MSI in 17\% of patients and concluded that MSI was associated with a significant survival advantage independent of all standard prognostic factors including tumour stage. Regardless of depth of tumour invasion, MSI-H CRC had a decreased likelihood of metastasis to regional lymph nodes. Elsaleh et. al. (2000) (mean age 66. $7 \pm 12$. 9 years) in Australia report striking survival benefits for patients with MSI tumours ( 90 vs $35 \%, p=0.0007$ ) and also for patients with right sided lesions, who received adjuvant chemotherapy as compared to those who did not ( 48 vs $27 \%$ alive at end of study, $\mathrm{p}<0.0001$ ) and for women (53 vs 33\%, p<0. 0001). Suh et. al. (2002) in a comparative study of MSI(+) and MSI(-) sporadic young (<40years) CRC patients showed that the former had better prognosis $(p=0.051)$. Their results suggested that sporadic MSI $(+)$ CRC in the young had different histomorphologic features as compared to MSI(-) CRC and HNPCC cancers. Samowitz et. al. (2009)in a study of 990 rectal cancer patients in the US showed that even though MSI-H has been associated in many studies with improved prognosis of colon cancer, the effect of MSI-H and K-ras mutations posed significantly higher risk of death for rectal cancers. Liang et. al. (2003) reported that there was a higher percentage of normal p53 expression (61 vs. 48\%) and high frequency microsatellite instability (MSI-H) (29. 4 vs. $6.3 \%$, p, 0. 001) in the young. Lukish et. al. (1998) in a study group of 36 patients in the $<40$ year age group determined their DNA replication error (RER) status (expressed as MSI) and compared the clinical and pathologic characteristics of RER(+) and RER(-) cases. They concluded that RER(+) tumours were common $(47 \%)$ in young patients and patients with $\operatorname{RER}(+)$ tumours had a significantly improved prognosis:5 year survival probability $68 \%$ in RER $(+), 32 \%$ in RER (-) tumours $(\mathrm{p}<0.05)$. Knowledge of RER status therefore could affect initial therapy, postoperative chemotherapy and follow up.

The paradoxical good survival after surgery for patients with young age at diagnosis of CRC supports the idea that many cancers in the young are microsatellite unstable. A number of studies linked high frequency MSI to poor tumour differentiation or mucinous histology, a signature of many tumours in the young (Sanchez et. al. 2009; Kim et. al. 1994, Lin et. al 2010, Suh et. al., 2002). Ionov et. al. (1993) in their study of mutations involving poly (dA. $\mathrm{dT}$ ) sequences (Section 5 for details) found that the presence of mutations was accompanied by an increase in the proportion of poorly differentiated lesions (6/9 vs 17/90, poor/well, moderate)and also in an increase in proportion of Stage $A+B$ disease (2/14 vs 53/68; $\mathrm{C}+\mathrm{D} / \mathrm{A}+\mathrm{B})$. Crude survival was expected to be better than usual in young patients because of their youth and the improved tolerance to surgery and complications that youth confers (Liang and Church 2010).

Berg et. al. (2010) in a study of patients in different age groups (Section 5 for details), found that patients with TP53 mutated tumours had poorer survival rates than patients with wild type TP53 (938 vs. 1016 days, $\mathrm{p}=0.04$ ); however the difference was not significant when corrected for tumour stage. TP53 mutation were of higher prognostic significance in right sided tumours $(883,1051$ days; mutated, wild type; $p=0.005)$. Among patients in the younger age group, those with K-ras mutation had significantly shorter survival than patients with K-ras wild type samples $(841,1033$ days, $\mathrm{p}=0.02)$.

Barnetson et. al. (2006) studied a group of 870 below-55 years CRC patients for germline mutations in DNA MMR genes, proposed a model for prediction of the presence of mutations in these genes and validated the model in an independent group of 155 patients. Survival in carriers and non carriers was similar. 


\section{Molecular genetics and treatment protocol}

Chemotherapeutic treatment protocol will progressively become more specific as the genetic basis of CRC gets better understood and the heterogeneity of the disease is better characterized. There are several literature reports that show these connections.

Fallik et. al. (2003) studied response to irinotecan in 72 patients, of whom 1 responded completely and 11 partially. Among the 7 tumours that displayed MSI-H phenotype, 4 responded to irinotecan whereas only 7 out of 65 MSI-L tumours did $(p=0.009)$. A better response to irinotecan was observed in the patients whose tumours have lost BAX expression $(p<0.001) .7$ of 72 tumours had inactivating mutations in the coding repeat of the target genes. Amongst these seven, five responded to irinotecan, whereas only 6 of the other 65 tumours did $(p<0.001)$ indicating that MSI-driven inactivation of target genes modifies tumour sensitivity. It has been shown that tumours with mucinous histology, a common feature of many tumours in the young(section 7) and whose molecular genetic signatures have been referred to earlier (section 3), show poor response to fluorouracil-based first line chemotherapy (Negri et. al. 2005) and first-line oxaliplatin /irinotecan based combination chemotherapy (Catalano et. al. 2009).

\section{Acknowledgement}

We thank Mr. Anil Kumar Verma and Dr. Nilanjana Bose.

\section{References}

Adkins RB Jr., DeLozier JB, McKnight WG, et. al. Carcinoma of the colon in patients 35 years of age and younger. Am Surg 1987; 53: 141-5.

Adloff M, Arnaud JP, Schloegel M et. al. Colorectal cancer in patients under 40 years of age. Dis Colon Rectum 1986; 29:322-5.

Ahlberg J, Bergstrand O, Holmstrom B, et. al. Malignant tumours of the colon and rectum in patients aged 30 and younger. Acta Chir Scand suppl 1980; 500:29-31.

Ahmed S, Banerjea A., Hands RE et. al.; Microarray profiling of colorectal cancer in Bangladeshi patients. Colorectal Dis. 2005; 7:571-5.

Alsop K, Mead L, Smith LD, et. al.; Low somatic K-ras mutation frequency in colorectal cancer diagnosed under the age of 45 years. European Journal of Cancer 2006; 42: 1357-61.

Ashenafi, S. The frequency of large bowel cancer as seen in Addis Ababa University, Pathology Department. Ethiop. Med. J. 2000; 38:277-82.

Baba S. Recent advances in molecular genetics of colorectal cancer. World J. Surg. 1997; 21: 678-87.

Bae JM, Jung KW, Won YJ. Estimation of cancer deaths in Korea for the upcoming years; J. Korean Med. Sci. 2002, 17:611-5.

Bamezai R, Singh G, Khanna NN et. al. Genetics of site specific colon cancer: a family study. Clin. Genet., 1984; 26: 129-32.

Barnetson RA, Tenesa A, Farrington SM. Identification and survival of carriers of mutations in DNA mismatch repair genes in colon cancer. N. Engl. J. Med. 2006; 354: 2751-3.

Beckman EN, Gathright JB, Ray JE. A potentially brighter prognosis for colon carcinoma in the third and fourth decades. Cancer 1984; 54:1478-81. 
Bedikian AY, Kantarjian H, Nelson RS, et al. Colorectal cancer in young adults. South Med J 1981;74:920-4.

Behbehani A, Sakwa M, Ehrlichman R, et. al. Colorectal carcinoma in patients under age 40. Ann. Surg. , 1985; 202: 610-4.

Berg M, Danielsen SA, Ahlquist T, et. al. ; DNA sequence profiles of the colorectal cancer critical gene set KRAS-BRAF-PIK3CA-PTEN-TP53 Related to Age at Disease Onset. PLoS ONE 2010; 5:e13978.

Beart RW Jr, Melton LJ, Maruta et. al. ; Trends in right and left sided colon cancer. Dis Colon Rectum 1983;26: 393-8.

Boland CR, Thibodeau SN , Hamilton SR et. al. A National Cancer Institute Workshop on Microsatellite Instability for cancer detection and familial predisposition: Development of International Criteria for the determination of Microsatellite Instability in colorectal cancer. Cancer Res 1998;58:5248-57.

Breivik J, Ragnhild AL, Gunn IM et. al. ; Different genetic pathways to proximal and distal colorectal cancer influenced by sex-related factors. Int. J. Cancer (Pred. Oncol. ), 1997; 74: 664-9.

Bulow S. Colorectal cancer in patients less than 40 years of age in Denmark, 1943-1967. Dis Colon Rectum 1980; 23: 327-36.

Calvert PM, Frucht H. The Genetics of Colorectal Cancer. Annals of Internal Medicine 2002; 137: 603-12.

Caspari R, Friedi W, Mandil M et. al. ; Familial adenomatous polyposis: mutation at codon 1309 and early onset of colon cancer. Lancet 1994; 343: 629-32 (Erratum in Lancet 1994; 343: 863).

Catalano V, Loupakis F, Graziano F. , et. al. Mucinous histology predicts for poor response rate and overall survival of patients with colorectal cancer and treated with firstline oxaliplatin- and/or irinotecan-based chemotherapy. Br J Cancer 2009; 100: 8817.

Chan TL, Yuen ST, Chung LP, et. al. Frequent Microsatellite Instability and mismatch repair gene mutations in Young Chinese patients with Colorectal cancer. J. Natl. Cancer Inst. 1999; 91:1221-6.

Chen CD, Yen MF, Wang WM et. al. A case-control study for the disease natural history of adenoma-carcinoma and de novo carcinoma and surveillance of colon and rectum after polypectomy: implication for efficacy of colonoscopy. Br J Cancer 2003; 88:1866-73.

Chew $\mathrm{MH}$, Koh PK, $\mathrm{Ng} \mathrm{KH}$. et. al.; Improved survival in an Asian cohort of young colorectal cancer patients. Ins. J. Colorectal Dis. 2009; 24: 1075-83.

Chiang JM, Chan MC, Changchien CR, et. al. Favorable influence of age on tumour characteristics of sporadx colorectal adenocarcinoma. Dis. Col. Rectum 2003; 46: 904-10.

Chung YFA, Eu KW, Machin D et. al. Young age is not a poor prognostic marker in colorectal cancer. British J. Surg. 1998; 85:1255-9.

Cozart DT, Lang NP, Hauer-Jensen M. ; Colorectal cancer in patients under 30 years of age. Contributors to the Southwestern Surgical Congress Unusual Case Registry. Am J Surg 1993;166:764-7.

Cusack JC, Giacco GG, Cleary K, et al. ; Survival factors in 186 patients younger than 40 years old with colorectal adenocarcinoma. J Am Coll Surg 1996;183:105-12. 
deSilva MV, Fernando MS, Fernando D. Comparison of some clinical and histological features of colorectal carcinoma occurring in patients below and above 40 years. Ceylon Med J 2000;45:166-8.

Dozois EJ, Boardman LA, Suwanthawna W. et. al. Young-Onset colorectal cancer in patients with no known genetic predisposition. Medicine 2008; 87: 259-63.

Durno C, Arnoson M, Bapat B, et. al. ; Family history and molecular features of children adolescents, and young adults with colorectal carcinoma. Gut. 2005; 54: 1146-50.

Durno CA, Gallinger S. Genetic predisposition to colorectal cancer: new pieces in the pediatric puzzle. J Pediatr Gastroenterol Nutr 2006; 43: 5-15.

Eaden JA, Abrams KR, Mayberry JT. The risk of colorectal cancer in ulcerative colitis: a metaanalysis. Gut 2001; 48: 526-35.

Elsaleh H, Joseph D, Grieu F. et. al. Association of tumour site and sex with survival benefit from adjuvant chemotherapy in colorectal cancer. The Lancet 2000; 355: 1745-50.

Endreseth BH, Romundstad P. Myrvold HE, et. al. ; Rectal Cancer in the young patient. Dis. Colon Rectum 2006; 49:993-1001.

Ewart Toland, A., Germline Genetics in Colorectal Cancer Susceptibility and Prognosis, Colorectal Cancer Biology - From Genes to Tumor, 2012.

Fairley TL, Cardinez CJ, Martin J et. al. Colorectal cancer in US Adults younger than 50 years of age, 1998-2001. Cancer 2006; 107: 1153-61.

Fallik D, Borrini F, Boige V, et. al.; Microsatellite instability is a predictive factor of the tumour response to irinotecan in patients with advanced colorectal cancer. Cancer Res. 2003; 63: 5738-44.

Fancher TT,Palesty JA,Rashidi L et. al.; Is Gender Related to the Stage of Colorectal Cancer at Initial Presentation in Young Patients? Journal of Surgical Reserch 2011;165,15-18

Fante R, Benatti P, diGregorio C. , et. al.; Colorectal carcinoma in different age groups: a population Fancher tbased investigation. Am. J. Gastroenterol 1997; 92: 1505-9.

Farrington SM, Lin-Goerke J, Ling J. et. al.; Systematic Analysis of hMSH2 and hMLH1 in young colon cancer patients and controls. Am. J. Hum. Genet. 1998; 63:749-59.

Fazeli MS, Adel MG, Lebaschi AH. Colorectal carcinoma: A retrospective, descriptive study of Age, Gender, sub site, stage and differentiation in Iran from 1995 to 2001 as observed in Tehran University. Dis. Colon Rectum, 2007; 50:990-5.

Fearon ER and Vogelstein B. A Genetic Model for Colorectal Tumorigenesis. Cell 1990; 61:759-67.

Fireman Z, Sandler E, Kopelman Y et. al. Ethnic differences in Colorectal Cancer among Arab and Jewish neighbours in Israel. Am. J. Gastroenterol, 2001;96:204-7.

Frizis A, Papadopoulos A, Akriditis G et. al. Are there any differences in colorectal cancer between young and older patients. Tech. Colorectal, 2004; 8 Supplement 1: s147-8.

Fry, R. D. , Mahmoud, N; Maron, D. J. et. al. (2008,18 th Ed;vol 2) in Sabiston Textbook of Surgery, Townsend CM, Beauchamp RD, Evers BM et. al. ; Elsevier, p 1404-5.

Fuchs CS, Guovannucci EL, Coldetz GA, et. al. A prospective study of family history and the risk of colorectal cancer. New England J. Of Medicine 1994; 331: 1669-74.

Goh KL, Quek KF, Yeo GTS et. al. Colorectal cancer in Asians: a demographic and anatomic survey in Malaysian patients undergoing colonoscopy. Aliment Pharmacol Ther 2005; 22: 859-64.

Goto H, Oda Y, Tanaka T, et. al. ; Estimated incidence of colorectal de novo cancer in Japan. Gut 2004: 53 (suppl 36): A30. 
Gryfe R, Swallow C, Bapat B et. al. Molecular biology of colorectal cancer. Curr Probl Cancer. 1997; 21: 23-300.

Gryfe R, Kim H, Hsieh ETK et. al. Tumour microsatellite instability and clinical outcome in young patients with colorectal cancer. New England J. of Medicine 2000; 342:69-77.

Gupta S, Bhattacharya D, Acharya AN et. al. Colorectal carcinoma in young adults: a retrospective study on Indian patients: 2000-2008. Colorectal Disease 2010; 12, e182-9.

Guraya SY, Eltinay OE. Higher prevalence in young population and rightward shift of colorectal carcinoma. Saudi Med J 2006; 27:1391-3.

Hamilton W. Letter to the Editor, Am. J. Surg. 2005; 189: 504.

Heys SD, O'Hanrahan TJ, Briltenden J, et. al. ; Colorectal cancer in young patients: a review of the literature. Eur. J. Surg. Oncol. 1994; 20: 225-31.

Hidalgo PM, Moreno SC, Moreno Gonzale E et. al. The incidence, prognostic factors and survival in young adults with colorectal adenocarcinoma. Rev. Esp Enfrm Dig. 1995; 87: 431-6.

Ho JWC,Yuen S,Chung L et. al. ,Distinct Clinical Features Associated With Microsattelite Instability In Clorectal Cancers Of Young Patients. Int. J. Cancer(Pred Oncol):2000;89:356-60

Hosseini SV, Izadpanah A, Yarmohammadi H. Epidemiological changes in colorectal cancer in Shiraz, Iran: 1980-2000. ANZ J Surg, 2004; 74: 547-9.

Howard E. W, Cavallo C, Hovey LM et. al. Colon Rectal cancer in the young adult; 1975; Am. Surg. 41:260-5.

Huang J, Seow A, Shi CY et. al. Colorectal Carcinoma among Ethnic Chinese in Singapore. Trends in Incidence Rate by Anatomic Sub site from 1968 to 1992. Cancer. 1999;85: 2519-25.

Ibrahim NK and Abdul Karim FW. Colorectal Adenocarcinoma in Young Lebanese adults. Cancer 1986; 58:816-20.

Isbister WH, Fraser J. Large-Bowel cancer in the young: a national survival study. Dis. Col. Rectum 1990; 33: 363-6.

Isbister WH. Colorectal cancer below age 40 in the Kingdom of Saudi Arabia. Aust NZJ. Surg. 1992; 62: 468-72.

Ionov Y,Peinado MA,Malkhosyan S. Ubiquitous somatic mutations in simple repeated sequences reveal a new mechanism for colonic carcinogenesis. Nature 1993; 363:558-61.

Jarvinen HJ, Turunen MJ. Colorectal carcinoma before 40 years of age: prognosis and predisposing conditions. Scand J Gastroenterol 1984; 19: 634-8.

Jass JR. Subsite distribution and incidence of colorectal cancer in New Zealand, 1974-1983. Dis Colon Rectum 1991; 34:56-9.

Jass, JR and Stewart, S. M. , Evolution of hereditary non-polyposis colorectal cancer. Gut, 1992; 33, 783-6.

Jass JR. Colorectal adenoma progression and genetic change: is there a link? Ann Med. 1995; 27: 301-6.

Johns LE \& Houlston RS; A systematic review and metaanalysis of familial colorectal cancer risk. Am. J. Gastroenterol 2001, 96, 2992-3003.

Kam MH, Eu KW, Barben CP et. al. Colorectal Cancer in the young: a 12 year review of patients 30 years or less. Colorectal Disease 2004; 6: 191-4.

Karsten B, Kim J, King J et. al. Characteristics of colorectal cancer in young patients at an urban county hospital. Am Surg. 2008; 74: 973-6. 
Kaw LL,Punzalan CK,Crisostomo AC et. al. Surgical Pathology of Colorectal Cancer in Filipinos:Implications for Clinical Practice. J. Am. Coll Surg 2002;195:188-95.

Khan SA, Idrees K, Forslund A, et. al. ; Genetic variants in germline TP53 and MDM2 SNP309 are not associated with early onset colorectal cancer. J Surg Oncol 2008; 97:621-5.

Kim H,Jen J,Vogelstein B et. al. Clinical and pathological characteristics of sporadic colorectal carcinomas with DNA replication errors in microsatellite sequences. Am. J Pathol. 1994;145:148-56.

LaQuaglia MP, Heller G, Filippa DA, et. al. ; Prognostic factors and outcome in patients 21 years and under with colorectal carcinoma. J. Pediatr. Surg. 1992; 27: 1085-90.

Lee PY, Fletcher WS, Sullivan ES, et al. Colorectal cancer in young patients: characteristics and outcome. Am Surg 1994; 60: 607-12.

Leff D. R. , Chen, A. , Roberts D. et. al. ; Colorectal cancer in the young patient. Am. Surg 2007; 73:42-7.

Lengauer C,Kinzler KW,Vogelstein B . Genetic instabilities in human cancers. Nature 1998;396:643-9.

Liang JT, Huang KC, Chen AL et. al. ; Clinicopathological and molecular biological features of colorectal cancer in patients less than 40 years of age. Br J Surg 2003; 19:205-14.

Liang J and Church J; How to Manage the patient with Early-Age-of-Onset $(<50$ years) Colorectal Cancer? Surg. Oncol Clin N Am 2010; 19:725-31.

Lichtman SM, Mandel F, Hoexter B et. al. Prospective Analysis of colorectal carcinoma. Dis. Colon. Rectum, 1994; 37:1286-90.

Lin JT, Wang WS, Yen CC, et. al. ; Outcome of colorectal carcinoma in patients under-40 years of age. J. Gastroenterol-Hepatol 2005; 20: 900-5.

Lin J-K, Shen M-Y, Lin T-C, et. al. Distribution of a single nucleotide polymorphism of insulin-like growth factor- 1 in colorectal cancer patients and its association with mucinous adeno carcinoma. Int. J. Biol. Markers 2010; 25: 195-9.

Liu B,Farrington SM,Peterson GM et. al. Genetic instability occurs in the majority of young patients with colorectal cancer. Nature Medicine 1995,1:348-52.

Loeb LA. Microsatellite Instability:Marker of a mutated phenotype in cancer. Cancer Research 1994;54:5059-63.

Losi L, Di Gregorio C, Pedroni M, et. al. ; Molecular genetic alterations and clinical features in early-onset colorectal carcinomas and their role for the recognition of hereditary cancer syndromes. Am J. Gastroenterol,2005;100:2280-7.

Lukish JR,Muro K,De Nobile J et. al. Prognostic significance of DNA Replication Errors in Young patients with Colorectal cancer. Annals of Surgery,1998,227:51-6.

Lynch, H. T. , Drouhard, T. J. , Schuelke, G. S. et. al. Hereditary nonpolyposis colorectal cancer in Navajo Indian family. Cancer Genet. Cytogenet. , 1985;15: 209-13.

Lynch, H. T. , Smyrk, T. C. ,Watson, P. et. al. ; Hereditary colorectal cancer. Semin. Oncol. , 1991; 18:337-66.

Lynch, H. T. Desmoid tumours:Genotype-Phenotype differences in familial adenomatous polyposis-A nosological dilemma. Am. J. Hum. Genet. ,1996;59:1184-5.

Lynch, H. T. , Smyrk, T. C. Classification of familial adenomatous polyposis:A diagnostic nightmare. Am. J. Hum. Genet. , 1998; 62: 1288-9.

Lynch HT, and de la Chapelle A; Genetic susceptibility to non-polyposis colorectal cancer. J. Med. Genet; 1999; 36: 801-18.

Lynch HT and de la Chapelle; Hereditary Colorectal Cancer. N. Engl J Med 2003;348:919-932. 
Mahadavinia M, Bishehsari F, Ansari R, et. al. ; Family history of colorectal cancer in Iran. BMC Cancer 2005; 5:112.

Makela J, Kiviniemi H, Laitinen S. Prognostic factors after surgery in patients younger than 50 years old with colorectal adenocarcinoma. Hepatogastroenterology. 2002; 49: 971-5.

Malekzadeh R, Bishehswin F, Mahdavinia M. et. al. Epidemiology and Molecular Genetics of Colorectal Cancer in Iran :A review. Arch. Iranian Mediane 2009; 12: 161-9.

Mecklin, J. P. , Frequency of hereditary colorectal carcinoma. Gastroenterology, 1987; 93, 1021-5.

Mecklin, J. P. and Jarvinen, H. J. , Tumor spectrum in cancer family syndrome (hereditary nonpolyposis colorectal cancer). Cancer, 1991; 68, 1109-12.

Mecklin, J. P. and Ponz de Leon, M. , Epidemiology of HNPCC. Anticancer Res. , 1994; 14, 1625-9.

Minardi AJ Jr, Sittig KM, Zibari GB, et al. Colorectal cancer in the young patient. Am Surg 1998;64:849-53.

Mitry E, Benhamiche AM, Jouve JL. Colorectal adenocarcinoma in patients under 45 years of age: comparison with older patients in a well-defined French population. Dis. Colon. Rectum 2001; 44: 380-87.

Mohandas KM, Desai DC. Epidemiology of digestive tract cancer in India. V. Large and small bowel. Indian J of Gastroenterol 1999; 18: 118-21.

Moore PA, Dilawari RA, Fidler WJ. Adenocarcinoma of the colon and rectum in patients less than 40 years of age. Am Surg 1984; 50: 10-4.

Morris M, Platell C, Iacopetta B. A population-based study of age-related variation in clinicopathological features, molecular markers and outcome from colorectal cancer. Anticancer Research 2007; 27:2833-8.

Murday V, and Slack J. , Inherited disorders associated with colorectal cancer. Cancer Surv. , 1989; 8, 139-57.

Nath J. , Wigley C. , Keighley MRB et. al. Rectal cancer in young adults: a series of 102 patients at a tertiary care centre in India. Colorectal Disease, 2009; 11:475-9.

National Cancer Registry Programme, Indian Council of Medical Research, NewDelhi. aConsolidated report of population based cancer registries(PBCR), 2001-4. December 2006, (supplement to Consolidated Report of Population Based Cancer Registries 1990-96:August 2001) www. icmr. nic. in bAtlas of Cancer in India (Chapter 7 of First All India Report 2001-02) National Cancer Registry Programme ICMR, www. canceratlasindia. org

Negri FV, Wotherspoon A, Cunnigham D, et. al. ; Mucinous histology predicts for reduced fluorouracil responsiveness and survival in advanced colorectal cancer. Annals of oncology 2005, 16: 1305-10.

Nelson RL, Dollear T, Freels S et. al. The relation of age, race, and gender to the subsite location of colorectal carcinoma. Cancer 1997;80:193-7.

Neufeld D, Shpitz B. Bugaev N. et. al. Young age onset of colorectal cancer in Israel. Tech. Coloproctal 2009; 13: 201-4.

$\mathrm{O}^{\prime}$ Connell JB, Maggard MA, Liu JH et. al. Rates of Colon and Rectal Cancers are increasing in young adults. Am. Surg. 2003; 69: 866-72.

O'Connell, J. B. , Maggard, M. A. , Livingston, E. H. et. al. Colorectal cancer in the young. The Am J Surg. 2004a;187:343-8. 
O'Connell J. B. , Maggard M. A. , Liu J. H. et. al. , Do young colon cancer patients have worse outcome? World J. Surg. 2004b; 28: 558-62.

Ohman U. Colorectal carcinoma in patients less than 40 years of age. Dis Colon Rectum 1982; 25:209-14.

Okuno M, Ikehara T, Nagayama M, et. al. Colorectal carcinoma in young adults. Am J Surg 1987; 154:264-8.

Pal, M. Proportionate increased in incidence of colorectal cancer at an age below 40 years: An observation. J. Can. Res. Ther. 2006; 2: 97-9.

Paraf F, Jothy S. Colorectal cancer before the age of 40: a case-control study. Dis. Col. Rectum 2000, 43: 1222-6.

Popat S, Hubner R, Houlston RS. Systematic review of microsatellite instability and colorectal cancer prognosis. J Clin Oncol 2005; 23: 609-18.

Potter JD. Colorectal Cancer:Molecules and population. J Natl Cancer Inst 1999;91:916-32.

Qing SH, Rao KY, Jiang HY et. al. Racial differences in the anatomical distribution of colorectal cancer: a study of differences between American and Chinese patients. World J Gastroenterol 2003; 9:721-5.

Rembacken BJ, Fujii T, Cairns A, et. al. Flat and depressed colonic neoplasms: a prospective study of 1000 colonoscopies in the UK. Lancet 2000; 355:1211-4.

Saltzstein SL, Behling CA, Savides TJ. The relation of age, race, and gender to the subsite location of colorectal carcinoma. Cancer 1998; 82:1408-10.

Samowitz WS, Curtin K, Wolff RK et. al. Microsatellite instability and survival in rectal cancer. Cancer Causes Control. 2009; 20: 1763-8.

Sanchez JA, Krumroy L, Plummer S. et. al. Genetic and epigentic classifications define clinical pheotypes and determine patient outcomes in colorectal cancer. Br J Surg 2009; 96:1196-204.

Sarroca, C. , Quadrelli, R. and Praderi, R. , Cancer colique familial. (Article in French) Nouv. Presse Med. , 1978;7: 1412.

Scarpa JF, Hartmann WH, Sawyers JL. Adenocarcinoma of the colon and rectum in young adults. South Med J 1976; 69: 24-7.

Shahrudin MD, Noori SM. Cancer of the colon and rectum in the first three decades of life. Hepatogastroenterology 1997;44:441-4.

Shemesh-Bar L, Kundel Y, Idelevich E. et. al. Colorectal cancer in young patients in Israel. World J. Surg. 2010; 34:2701-9.

Singh JP, Maini VK and Bhatnagar A. Large Bowel Malignancy; Epidemiology and gut Motility Studies in South Asia. Dis. Colon. Rectum 1984; 27: 10-15.

Singh Y, Vaidya P, Hemandas AK et. al. Colorectal carcinoma in Nepalese young adults: presentation and outcome. Gan To Kagaku Ryoho. 2002a; 29 Suppl 1:223-9.

Singh LJ, Moirangthem GS, Debnath K. Colorectal cancer in younger patients. Trop Gastroenterol 2002b; 23:144-5.

Slattery ML, Friedman GD, Potter JD et. al. Description of age, sex and site distributions of colon carcinoma in three geographic areas. Cancer, 1996; 78: 1666-70.

Soliman AS, Bondy ML, Levin B. et. al. Colorectal cancer in Egyptian patients under 40 years of age. Int. J. Cancer 1997; 71: 26-30.

Soliman AS, Bondy ML, El-Badawy SA et. al. Contrasting molecular pathology of colorectal carcinoma in Egyptian and Western patients ,British Journal of Cancer 2001; 85(7): 1037-1046. 
St. John DJB, McDermott FT, Hopper JL et. al. Cancer Risk in Relatives of Patients with Common colorectal cancer. Annals of internal Medicine 1993; 118: 785-90.

Stigliano V, Assisi D, Cosimelli M, et. al. ; Survival of hereditary non-polyposis colorectal cancer patients compared with sporadic colorectal cancer patients. J. Exp. Clin. Cancer Res 2008; 27: 39.

Suh JH, Lim SD, Kim JC, et. al. ; Comparison of clinicopathologic characteristics and genetic alterations between microsatellite instability-positive and microsatellite instabilitynegative sporadic colorectal carcinomas in patients younger than 40 years old. Dis. Colon Rectum 2002; 45: 219-28.

Sung JJY, Lau JY, Goh KL et. al. Increasing incidence of colorectal cancer in Asia: implications for screening. Lancet Oncol. 2005;6: 871-6.

Tamura K, Ishiguro S, Munakata A et. al. Annual changes in colorectal carcinoma incidence in Japan. Analysis of survey data on incidence in Aomori Prefecture. Cancer 1996; 78: 1187-94.

Thibodeau SN, Bren G, Schaid D . Microsatellite Instability in Cancer of the Proximal Colon. SCIENCE 1993;260:816-9

Tohme C, Labaki M, Hajj G, et. al. ; Colorectal cancer in young patients: presentation, clinicopathological characteristics and outcome. J. Med. Liban, 2008; 56: 208-14 (Article in French).

Turkiewich D, Miller B, Schache D et. al. Young patients with colorectal cancer: how to they fare. ANZ J. Surg 2001; 71: 707-10.

Ushio, K., Genetic and familial factors in colorectal cancer. J. clin. Oncol. , 1985; 15(Suppl. 1), 281-98.

Varma JR, Sample L. Colorectal cancer in patients aged less than 40 years. J Am Board Fam Pract 1990; 3: 54-9.

Vasen, H. F., Offerhaus, G. J. , Den Hartog Jager, F. C. et. al. The tumor spectrum in hereditary non-polyposis colorectal cancer: a study of 24 kindreds in the Netherlands. Int. J. Cancer, 1990; 46, 31-4.

Walton WW, Hagihara PG, Griffen WO. Colorectal Adenocarcinoma in Patients Less than 40 Years Old; Dis Colon and Rectum, 1976; 19: 529-34.

Winawer SJ, Zauber AG, Gerdes H, et. al. ; Risk of colorectal cancer in the families of patients with adenomatous polyps. National Polyp Study Workgroup. The N. England J. of Med 1996; 334:82-7.

www. Cancer. org

Yang VW. The Molecular Genetics of Colorectal Cancer; Current Gastroenterology Reports1999;1:449-54

Yantiss RK, Goodarzi M, Zhou XK et. al. ; Clinical pathologic and molecular features of early onset colorectal carcinoma. Am J Surg Pathol 2009; 33: 572-82.

Yilmazlar T, Zorluoglu A, Ozguc H, et. al. ; Colorectal cancer in young adults, 1995; 81:230-3.

Yiu HY, Whittemore AS, Shibata A. Increasing colorectal cancer incidence rates in Japan. International Journal of Cancer, 2004; 109: 777-81.

Yuen ST, Chung LP and Leung SY. Colorectal carcinoma in Hong Kong, epidemiology and genetic mutation. Brit. J. Cancer; 1997; 76: 1610-6.

Zbuk K, Sidebotham EL, Bleyer A. et. al. , Colorectal cancer in young adults. Seminars in Oncology 2009; 36: 439-50. 


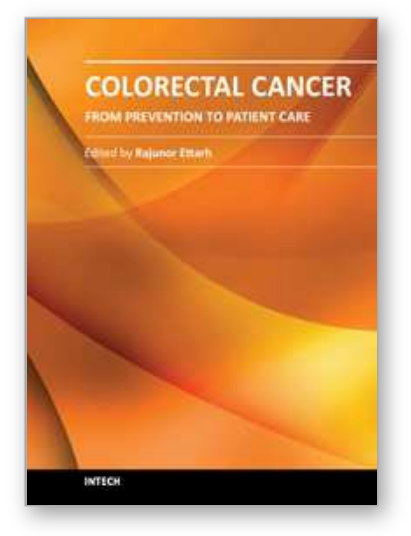

\author{
Colorectal Cancer - From Prevention to Patient Care \\ Edited by Dr. Rajunor Ettarh
}

ISBN 978-953-51-0028-7

Hard cover, 538 pages

Publisher InTech

Published online 17, February, 2012

Published in print edition February, 2012

The projections for future growth in the number of new patients with colorectal cancer in most parts of the world remain unfavorable. When we consider the substantial morbidity and mortality that accompanies the disease, the acute need for improvements and better solutions in patient care becomes evident. This volume, organized in five sections, represents a synopsis of the significant efforts from scientists, clinicians and investigators towards finding improvements in different patient care aspects including nutrition, diagnostic approaches, treatment strategies with the addition of some novel therapeutic approaches, and prevention. For scientists involved in investigations that explore fundamental cellular events in colorectal cancer, this volume provides a framework for translational integration of cell biological and clinical information. Clinicians as well as other healthcare professionals involved in patient management for colorectal cancer will find this volume useful.

\title{
How to reference
}

In order to correctly reference this scholarly work, feel free to copy and paste the following:

Shahana Gupta and Anadi Nath Acharya (2012). Colorectal Carcinoma in the Young, Colorectal Cancer From Prevention to Patient Care, Dr. Rajunor Ettarh (Ed.), ISBN: 978-953-51-0028-7, InTech, Available from: http://www.intechopen.com/books/colorectal-cancer-from-prevention-to-patient-care/colorectal-carcinoma-inthe-young

\section{INTECH}

open science | open minds

\author{
InTech Europe \\ University Campus STeP Ri \\ Slavka Krautzeka 83/A \\ 51000 Rijeka, Croatia \\ Phone: +385 (51) 770447 \\ Fax: +385 (51) 686166 \\ www.intechopen.com
}

\author{
InTech China \\ Unit 405, Office Block, Hotel Equatorial Shanghai \\ No.65, Yan An Road (West), Shanghai, 200040, China \\ 中国上海市延安西路65号上海国际贵都大饭店办公楼 405 单元 \\ Phone: +86-21-62489820 \\ Fax: $+86-21-62489821$
}


(C) 2012 The Author(s). Licensee IntechOpen. This is an open access article distributed under the terms of the Creative Commons Attribution 3.0 License, which permits unrestricted use, distribution, and reproduction in any medium, provided the original work is properly cited. 